\title{
Review \\ Cisplatin Resistance and Redox-Metabolic Vulnerability: A Second Alteration
}

\author{
Medhi Wangpaichitr ${ }^{1,2, *}$, George Theodoropoulos ${ }^{1}$, Dan J. M. Nguyen ${ }^{1}$, Chunjing Wu ${ }^{1}$, Sydney A. Spector ${ }^{1}$, \\ Lynn G. Feun ${ }^{3}$ and Niramol Savaraj ${ }^{3,4}$
}

1 Department of Veterans Affairs, Miami VA Healthcare System, Research Service (151), Miami, FL 33125, USA; theogengr@yahoo.com (G.T.); j.nguyen3@miami.edu (D.J.M.N.); chunjing.wu@va.gov (C.W.); sydney.spector@va.gov (S.A.S.)

2 Department of Surgery, Cardiothoracic Surgery, Miller School of Medicine, University of Miami, Miami, FL 33136, USA

3 Department of Medicine, Hematology/Oncology, Miller School of Medicine, University of Miami, Miami, FL 33136, USA; lfeun@med.miami.edu (L.G.F.); nsavaraj@med.miami.edu (N.S.)

4 Department of Veterans Affairs, Miami VA Healthcare System, Hematology/Oncology, 1201 NW 16 Street, Room D1010, Miami, FL 33125, USA

* Correspondence: mwangpaichitr@med.miami.edu; Tel.: +1-305-575-7000 (ext. 14496); Fax: +1-305-575-7275

Citation: Wangpaichitr, M.;

Theodoropoulos, G.; Nguyen, D.J.M.;

Wu, C.; Spector, S.A.; Feun, L.G.;

Savaraj, N. Cisplatin Resistance and Redox-Metabolic Vulnerability: A Second Alteration. Int. J. Mol. Sci. 2021, 22, 7379. https://doi.org/ $10.3390 /$ ijms 22147379

Academic Editor: Claudiu T. Supuran

Received: 8 June 2021

Accepted: 5 July 2021

Published: 9 July 2021

Publisher's Note: MDPI stays neutral with regard to jurisdictional claims in published maps and institutional affiliations.

Copyright: (c) 2021 by the authors. Licensee MDPI, Basel, Switzerland. This article is an open access article distributed under the terms and conditions of the Creative Commons Attribution (CC BY) license (https:// creativecommons.org/licenses/by/ $4.0 /)$.

\begin{abstract}
The development of drug resistance in tumors is a major obstacle to effective cancer chemotherapy and represents one of the most significant complications to improving long-term patient outcomes. Despite early positive responsiveness to platinum-based chemotherapy, the majority of lung cancer patients develop resistance. The development of a new combination therapy targeting cisplatin-resistant (CR) tumors may mark a major improvement as salvage therapy in these patients. The recent resurgence in research into cellular metabolism has again confirmed that cancer cells utilize aerobic glycolysis ("the Warburg effect") to produce energy. Hence, this observation still remains a characteristic hallmark of altered metabolism in certain cancer cells. However, recent evidence promotes another concept wherein some tumors that acquire resistance to cisplatin undergo further metabolic alterations that increase tumor reliance on oxidative metabolism (OXMET) instead of glycolysis. Our review focuses on molecular changes that occur in tumors due to the relationship between metabolic demands and the importance of $\mathrm{NAD}^{+}$in redox (ROS) metabolism and the crosstalk between PARP-1 (Poly (ADP ribose) polymerase-1) and SIRTs (sirtuins) in CR tumors. Finally, we discuss a role for the tumor metabolites of the kynurenine pathway (tryptophan catabolism) as effectors of immune cells in the tumor microenvironment during acquisition of resistance in CR cells. Understanding these concepts will form the basis for future targeting of CR cells by exploiting redox-metabolic changes and their consequences on immune cells in the tumor microenvironment as a new approach to improve overall therapeutic outcomes and survival in patients who fail cisplatin.
\end{abstract}

Keywords: cisplatin resistance; metabolism; oxidative metabolism; reactive oxygen species

\section{Introduction}

Cisplatin is an active agent that is widely used in the treatment of several types of solid tumors and has been a gold standard in the treatment of many types of cancer, including lung (both small cell and non-small cell lung cancer), head and neck cancer, and ovarian cancer [1-3]. Cisplatin-induced toxicity involves various mechanisms, such as DNA adduct formation, mitochondrial dysfunction, and oxidative stress [4] The majority of patients will initially respond to cisplatin treatment; however, resistance to cisplatin is inevitable. The development of cisplatin resistance is complex and involves multiple mechanisms, which makes it difficult to overcome. Thus far, there are no available drugs that can reverse cisplatin resistance or selectively kill cisplatin-resistant (CR) cells. 
It has become apparent that cancer cells rewire their metabolic reliance to glycolysis to promote growth, survival, and proliferation [5]. This is considered the "first" metabolic switch along their survival path. Nevertheless, emerging evidence implicates that CR cells undergo additional metabolic reprogramming wherein tumors become more reliant on oxidative metabolism (OXMET), resulting in higher accumulation of ROS [6-8]. Thus, alteration in redox status by modulation of ROS can influence cellular sensitivity to cisplatin.

The exact mechanism for a "second" metabolic switch from glycolysis to OXMET in the development of cisplatin-resistant tumor cells has not been elucidated. In this review, we summarize additional alterations in redox-metabolism that play a vital role in adaptive resistance to cisplatin and cellular metabolism. Furthermore, we focus on the features of tumor metabolism and redox as well as the kynurenine pathway (tryptophan catabolism) in relation to cisplatin resistance and propose how exploiting metabolic pathways could overcome drug resistance.

\section{Cancer Cell and Metabolic Demand}

Most if not all cancer cells are known to increase glycolysis demand to adapt with high proliferation rate and growth. Under aerobic glycolysis, cancer cells can rapidly produce building blocks such as ribonucleotides and amino acids as well as adenosine triphosphate (ATP). Because of rapid growth, this population of cancer cells are the target for standard chemotherapeutic agents such as cisplatin. More importantly, tumors utilize glycolysis instead of oxidative phosphorylation (OXPHOS) even with adequate supply of oxygen as their primary source of energy ("Warburg effect") $[9,10]$. This effect may not be due to defective mitochondrial respiration but rather due to upregulation of glycolytic enzymes and glucose transporters [11,12]. However, there are also reports indicating that many types of cancer are indeed associated with mutations in TCA cycle enzymes [13-15]. Together, it is evident that the "first" metabolic switch from normal to cancer cell reprograms cells to glucose addiction; as a consequence, increased glucose uptake becomes one of the hallmarks for malignant transformation [16]. Due to this difference in energy metabolism between tumor and normal tissue, uptake of glucose analogs (fluoro-deoxy-glucose) has been utilized successfully in the development of a diagnostic imaging technique, fluoro-deoxyglucose positron emission tomography (FDG-PET) for cancer detection [17]. However, PET-negative results (not taking up FDG) after chemotherapy does not always correlate with tumor response and can lead to detrimental false negative results. Based on these phenomena, we are firmly convinced that cancer cells undergo a "second" major metabolic rewiring when they acquire resistance to chemotherapy such as cisplatin.

\subsection{Cisplatin Resistance and Glucose Metabolism}

A straightforward scheme for cells to resist a cytotoxic drug is to not absorb it. Thus, decreased cisplatin accumulation is one of the most important mechanisms of resistance found in CR cells. Decreased hTCR1 (a copper transporter pump) expression, which transports cisplatin inside cells, has been shown to be one of the major contributory factors to decreased intracellular cisplatin accumulation $[18,19]$. Over-expression of hCTR1 signifies better response rates, better progression free survival, and overall survival among patients with stage III non-small-cell lung cancer [20]. Corresponding with this occurrence, it was recently shown that glucose consumption and uptake in CR cells is reduced in comparison with cisplatin-sensitive cells. The reduction in glucose consumption and uptake is due to the loss of glucose transporter-1 (GLUT1) expression on the plasma membrane of CR cells [21]. Hence, it is conceivable that the development of cisplatin resistance in cancer cells is the consequence of metabolic reprograming from glycolytic metabolism to oxidative metabolism (OXMET). By utilizing OXMET instead of glucose, $\mathrm{CR}$ cells slow down proliferation, which aids in escaping the effects of cisplatin, which is designed to target fast dividing cells. Importantly, metabolic changes in CR cells cause abnormal mitochondrial functions, such as electron leak, which in turn results in higher levels of mitochondrial reactive oxygen species (ROS) [21,22]. Increased ROS can facilitate 
the activation of receptor tyrosine kinase signaling as well as PI3K/AKT, which plays a vital role in cell growth/proliferation, survival, and motility [23,24] (Figure 1).

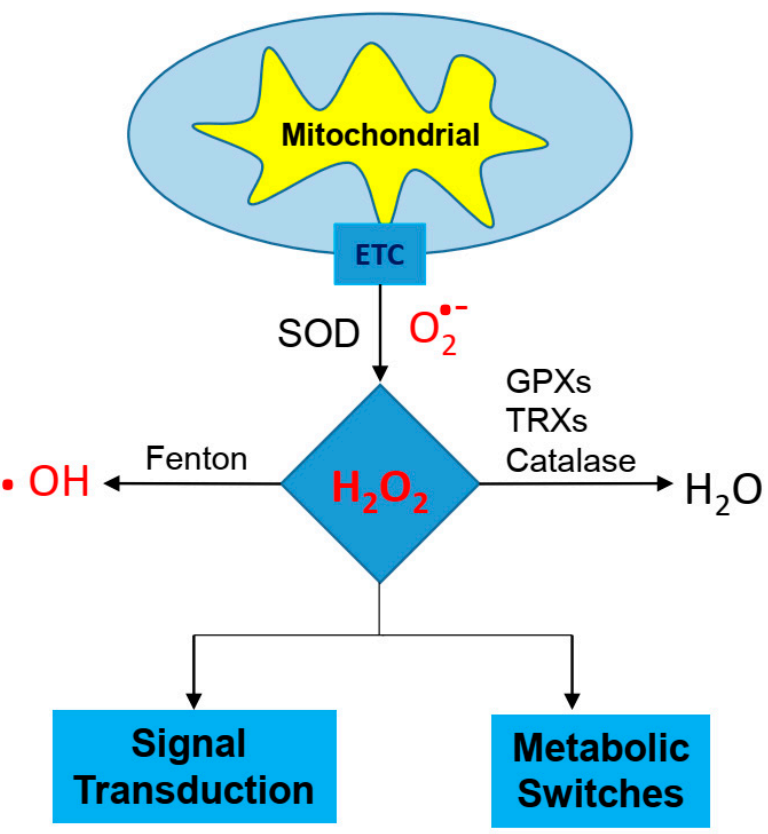

Figure 1. Electron leak generates from the electron transport chain of the mitochondria. Superoxide dismutase (SOD) enzymes convert superoxide molecules into a $\mathrm{H}_{2} \mathrm{O}_{2}$, which can then be reduced to water by glutathione peroxidases (GPXs), thioredoxins (TRXs), or catalase to water $\left(\mathrm{H}_{2} \mathrm{O}\right)$ molecules. Hydrogen peroxide can activate the signaling pathway and metabolic adaptations.

Additionally, lowered expression of key glycolytic enzymes is reported in CR cells compared with cisplatin-sensitive cells. For instance, the expression of hexokinase-2 (HK2) and lactic dehydrogenase-A (LDHA) is reported to be significantly lower in cisplatinresistant cells compared with sensitive cells [25]. This finding points to a concept where the glycolytic pathway is not as active in CR tumors compared with sensitive tumors. Furthermore, the decreased expression of LDHA coincides with decreased lactate production from CR cells compared with sensitive cells, also signaling that cisplatin-resistant cells no longer depend on glycolysis. We have found that cisplatin-treated and already-resistant cells (CR), expressing low levels of the final rate-limiting enzyme of the glycolytic pathway, PKM2, have survived treatment and consume more oxygen and produce less lactate, indicating a shift toward OXMET utilization [26]. In addition to our work, other studies have shown that PKM2 protein and activity levels were lower in CR human gastric carcinoma cell lines compared with their parental cell lines. Further suppression of PKM2 expression using antisense oligonucleotides increased cisplatin resistance in these CR cells [27]. In a clinical study, PKM2 mRNA levels were measured in tumors treated with oxaliplatin in combination with 5-fluorouracil, and the tumors with the lowest levels of PKM2 attained the lowest response rates to treatment [28]. In contrast to these findings, others showed that increased PKM2 levels have been linked with resistance to 5-fluorouracil in patients with colorectal cancer [29]. Moreover, eliminating expression of PKM2 in some naïve cells is reported to re-sensitize tumor cells to platinum-based therapies [30-33]. These studies hint that resistance mechanisms are tissue specific and resistance specific. Genetic silencing of PKM2 increased the efficacy of docetaxel- and cisplatin-mediated cell death in in vitro and lung cancer xenograft models [34,35]. These conflicting reports and the lack of a definitive role for PKM2 in the development of drug resistance have raised concerns about the potential of PKM2 as a valid cancer drug target. Nonetheless, it is irrefutable that $\mathrm{CR}$ cells rewire glycolytic metabolism for a survival advantage. 


\subsection{Cisplatin Resistance and Glutamine Anaplerosis}

Since CR cells are not primarily reliant on glucose, they must be dependent on other carbon skeleton sources to survive. By utilizing OXMET, CR cells can metabolize glutamine to glutamate via the glutaminase (GLS) enzyme. Glutamate will then serve as an anaplerosis substrate for alpha keto-glutarate in the TCA cycle on which OXMET is dependent (Figure 2). With this modification in energy sourcing, it has been shown that CR cells consume more glutamine [6]. Importantly, CR cells have increased cellular energy or metabolic demand that outstrips the glutamine supply, making glutamine the conditionally essential amino acid for cell survival. We and others have shown that $\mathrm{CR}$ cell growth was very sensitive to glutamine deprivation, and confirmed that cells were unable to survive in glutamine-free media $[6,36,37]$. These finding were further supported when the exposure to the combination of glutaminase inhibitor (BPTES) and a platinum-based agent synergistically inhibited platinum-resistant ovarian cancers in vitro [36]. Hence, there are ample data at this time to support a dependence on glutamine in CR cells that rely on OXMET and the TCA cycle.

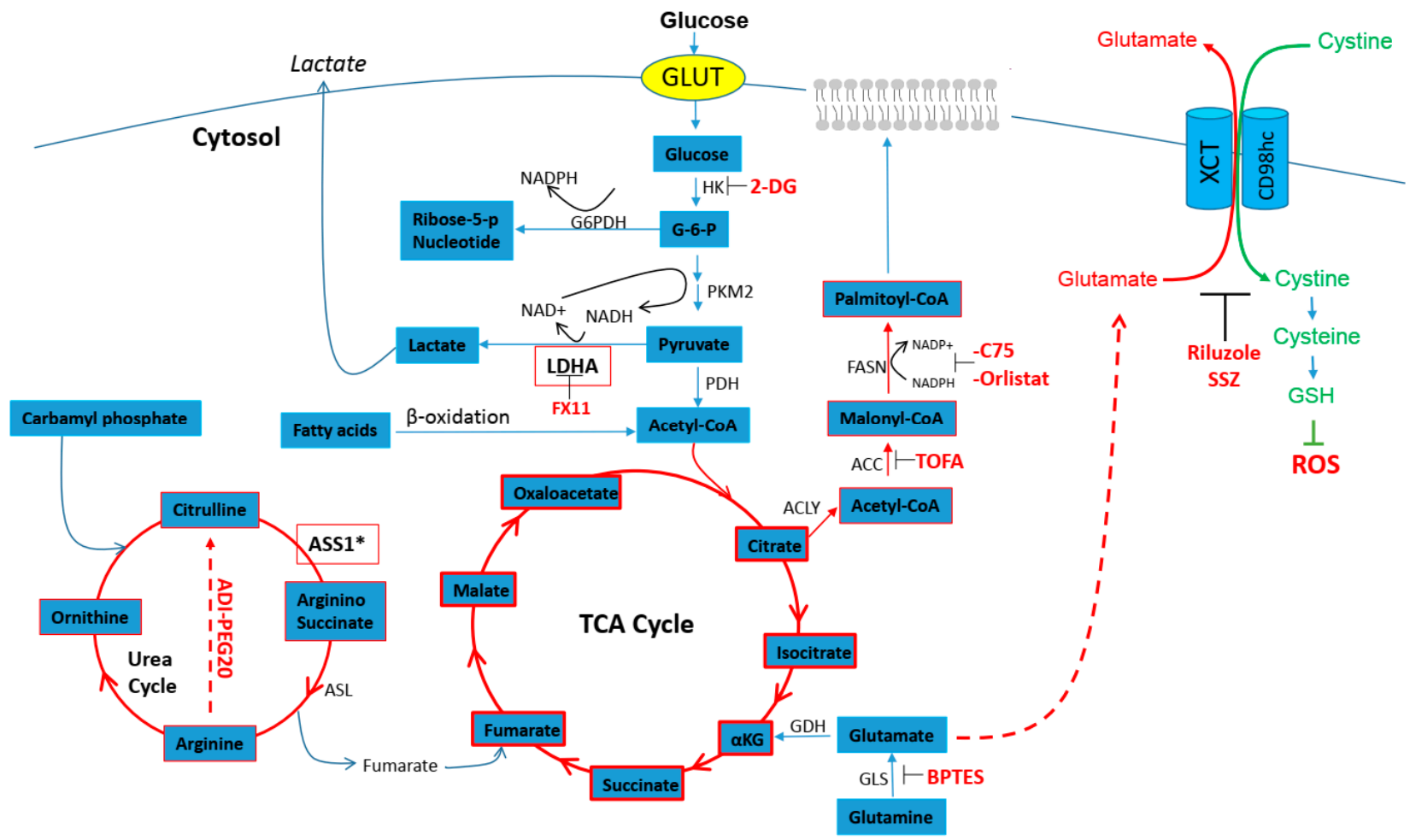

Figure 2. Metabolic scheme of bioenergetics and anabolic metabolism in cancer cells that represent treatment targets. CR cells take up large amounts of glutamine and use these nutrients to fuel the tricarboxylic acid (TCA) cycle and oxidative phosphorylation (OXPHOS). Glutamine is hydrolyzed to glutamate for glutathione synthesis, an essential factor to abrogate high ROS via xCT antiporter. Increased fatty acid synthesis enzymes are also found in CR tumors. Moreover, tumors lacking ASS1 enzyme in the urea cycle require extracellular arginine in the circulation for survival. ACLY = ATP citrate lyase, ACC $=$ acetylCoA carboxylase, ADI-PEG = arginine deiminase pegylated-20, ASL = argininosuccinate lyase, ASS1 = argininosuccinate synthetase, BPTES = glutaminase inhibitor, CD98hc = CD98 heavy chain, 2-DG = 2-deoxy-d-glucose, FX= LDHA inhibitor, FASN = fatty acid synthase, G-6-P = glucose-6-phosphate, G6PDH = glucose-6-P dehydrogenase, GLS = glutaminase, $\mathrm{GDH}=$ glutamate dehydrogenase, GLUT = glucose transporter, $\mathrm{GSH}=$ glutathione, $\mathrm{HK}=$ hexokinase, $\alpha-\mathrm{KG}=$ alphaketoneglutarate, $\mathrm{LDHA}=$ lactate dehydrogenase-A, $\mathrm{PDH}=$ pyruvate dehydrogenase, $\mathrm{PKM} 2=$ pyruvate kinase isozymes $\mathrm{M} 2, \mathrm{PPP}=$ pentose phosphate pathway. $\mathrm{ROS}=$ reactive oxygen species, $\mathrm{SSZ}=$ Sulfasalazine, $\mathrm{TCA}=$ tricarboxylic acid, $\mathrm{XCT}=$ system $\mathrm{x}_{\mathrm{C}}{ }^{-}$amino-acid transporter.

The higher consumption of glutamine served as an indicator that CR cells undergo a "second" metabolic reprograming. Some reports have shown that glutamine imported 
into cells is not totally utilized for anabolic metabolism [37]. Rather, a portion of glutamine/glutamate is shuttled out of the cell in exchange for amino acids inside the cell that directly activate mTOR (the mammalian target of rapamycin), which is a significant component of the PI3K family of protein kinases in cellular proliferation [38,39]. In fact, increased glutamate efflux is an important process for cells to generate glutathione (GSH) to cope with high intracellular ROS levels. This process is carried out through the $x_{c}{ }^{-}$ system, a cystine-glutamate exchange transporter on the membrane composed of the $\mathrm{xCT}$ subunit, wherein glutamate is removed from the cell while cysteine is imported and later forms GSH (Figure 2) [40]. Cysteine is considered the rate-limiting precursor in this process. Sulfasalazine (SSZ), a known inhibitor of the $\mathbf{x}_{\mathbf{c}}{ }^{-}$system pump $[41,42]$ had a synergistic effect when used in combination with cisplatin in colon cancer [43]. These investigators believed that cancers with increased expression of $x_{c}{ }^{-}$on the membrane may be more susceptible to cisplatin treatment. In addition, we also showed that blocking glutamate efflux by riluzole (an FDA-approved drug for amyotrophic lateral sclerosis and effective inhibitor of the $\mathrm{xCT} /$ cystine/glutamate pump) can selectively kill CR cells in vitro and in vivo [6]. In the treated cells, glutamate secretion was decreased since the cysteine antiport was inhibited, leading to elevated ROS and cell death without co-treatment with cisplatin. Moreover, riluzole can further decrease NAD+ (nicotinamide adenine dinucleotide) and LDHA expression, which in turn heightens oxidative stress in CR cells [6].

\subsection{Cisplatin Resistance and Urea Cycle}

Similar amino acid therapeutic approaches are being investigated for the treatment of arginine auxotrophic tumors. There are numerous reports of tumors such as melanoma, mesothelioma, prostate cancer, and hepatoma that are auxotrophic for arginine [44-47]. These tumors have low or no expression of argininosuccinate synthetase-1 (ASS1), which is a key enzyme in the urea cycle that catalyzes the synthesis of arginine from citrulline (Figure 2). Thus, the lack of ASS1 expression makes arginine an essential amino acid in these tumors.

Moreover, downregulation of ASS1 expression has been linked to poor prognosis with increased proliferation and invasion of cancer cells [48,49]. Methylation of the CpG islands within the ASS1 promoter has been reported many times as one of the mechanisms responsible for the loss of ASS1 expression in solid tumors [48,50,51]. Furthermore, patients treated with first-line platinum/paclitaxel for ovarian cancer had a poor overall and disease-free survival in tumors exhibiting methylated ASS1 compared with unmethylated ASS1 [50,52].

Interestingly, it has been shown that the epigenetic inactivation of ASS1 can be associated with selective resistance to platinum-based treatment in primary ovarian cancercultured cells [52]. Consistent with this finding, we also reported ASS1 silencing in ovarian cancer that acquired resistance to cisplatin [51]. ASS1 suppression is controlled by the transcriptional repressor HIF-1 $\alpha$, which occupies the E-box at the ASS1 promoter and blocks c-MYC from binding [51]. De-repression of ASS1 from HIF- $1 \alpha$ binding allows c-Myc to activate ASS1 expression [53]. Tumors lacking the ASS1 enzyme require extracellular arginine in the circulation for survival [54-56]. Arginine deprivation therapy using the arginine degrading enzyme ADI-PEG20 (pegylated arginine deiminase) or human arginase 1 has been in various stages of clinical evaluation for targeting Arg-auxotrophic tumors [55]. ADI-PEG20 digests arginine into citrulline and ammonia [57], and human arginase 1 digests arginine into ornithine and urea [56]. ADI-PEG20 is safe, and the drug is only effective in patients whose tumors are negative for ASS protein expression. Together, these findings highlight the potential of arginine deprivation therapy as a strategy to overcome resistance to platinum-based drugs.

\subsection{Cisplatin Resistance and Fatty Acids}

In addition to amino acid metabolism having an increasing role in cisplatin resistance, emerging reports showed that upregulation of fatty acid synthesis is associated with poor 
prognosis [58-60] and that overexpression of fatty acid synthase (FASN; key regulator of the de novo synthesis of fatty acids) is correlated with markers of cellular proliferation [61] and interferes with drug efficacy [62]. Inhibiting FASN using orlistat can reverse acquired resistance to trastuzumab in breast and ovarian cancer cells $[63,64]$, as well as hyper-sensitize breast cancer cells to doxorubicin, docetaxel, paclitaxel, or vinorelbine $[65,66]$. Others have shown that over-expression of FASN can be a predictive marker for cisplatin resistance and that inhibiting FASN can overcome cisplatin resistance in mice bearing breast cancer xenografts [67]. Moreover, combination treatment of C75 (FASN inhibitor) and cisplatin resulted in greater growth inhibition of ovarian cancer in vivo than cisplatin treatment alone [61]. Studies also suggested that FASN inhibition may work beyond suppression of FASN activity. It has been shown that FASN reduced both the expression of multidrug resistance protein (MDR) and multidrug resistance-associated protein (MRP-1) types of $\mathrm{ABC}$ membrane transporters that are practically ubiquitously expressed in tissues and found to pump chemotherapeutic agents out of cells $[68,69]$. Consistent with these findings, we also reported that CR lung cancer cells that over-expressed homolog MRP-4 [70] also possessed 15-fold more acetyl-CoA carboxylase (ACC; first enzyme in the committed step of fatty acid synthesis), and 5-fold more FASN when compared with parental cell counterparts [22]. Thus, overexpressing all the previously mentioned molecules that contribute to drug resistance and survival in the scheme described herein involves fatty acid synthesis. We also reported that TOFA (an allosteric inhibitor of ACC that blocks the synthesis of malonyl CoA) or C75 (FASN inhibitor) induced significant cell death in CR cells [22]. Overall, the data illustrated that modulation of fatty acid metabolism is an acquired resistance mechanism whose inhibition may represent a novel strategy for the treatment of tumors that are resistant to cisplatin.

\section{Cancer Cell and Redox Balance}

One of the mechanisms of cisplatin resistance development is connected to the influence of ROS-induced damage to DNA and cellular molecules. Under normal physiological conditions, ROS is tightly regulated by the balance between its production (oxidant) and both enzymatic and non-enzymatic elimination (antioxidant). To avoid oxidative damage, ROS is detoxified by catalase and two other systems: glutathione (GSH) and thioredoxin (TRX) [71-73]. In these systems, NADPH is required for regeneration of GSH and TRX through glutathione reductase and thioredoxin reductase, respectively [74,75]. NADPH also reactivates catalase when catalase is inactivated by $\mathrm{H}_{2} \mathrm{O}_{2}$ [76]. Contrary to the role of $\mathrm{NADPH}$, studies have shown that NADPH could also significantly contribute to generation of oxidative stress through the activity of NADPH oxidase [77,78]. NADPH oxidase (NOX) is an enzyme that catalyzes the generation of intracellular superoxide from oxygen and NADPH (Figure 3). Increasing evidence has indicated that NOX activity is present not only in phagocytes but also in various tissues and cell types $[77,79]$. Importantly, NOX expressions have been involved with cisplatin resistance [80]. Therefore, it is clear that the alteration in redox status via ROS modulation can influence cellular sensitivity to cisplatin. 


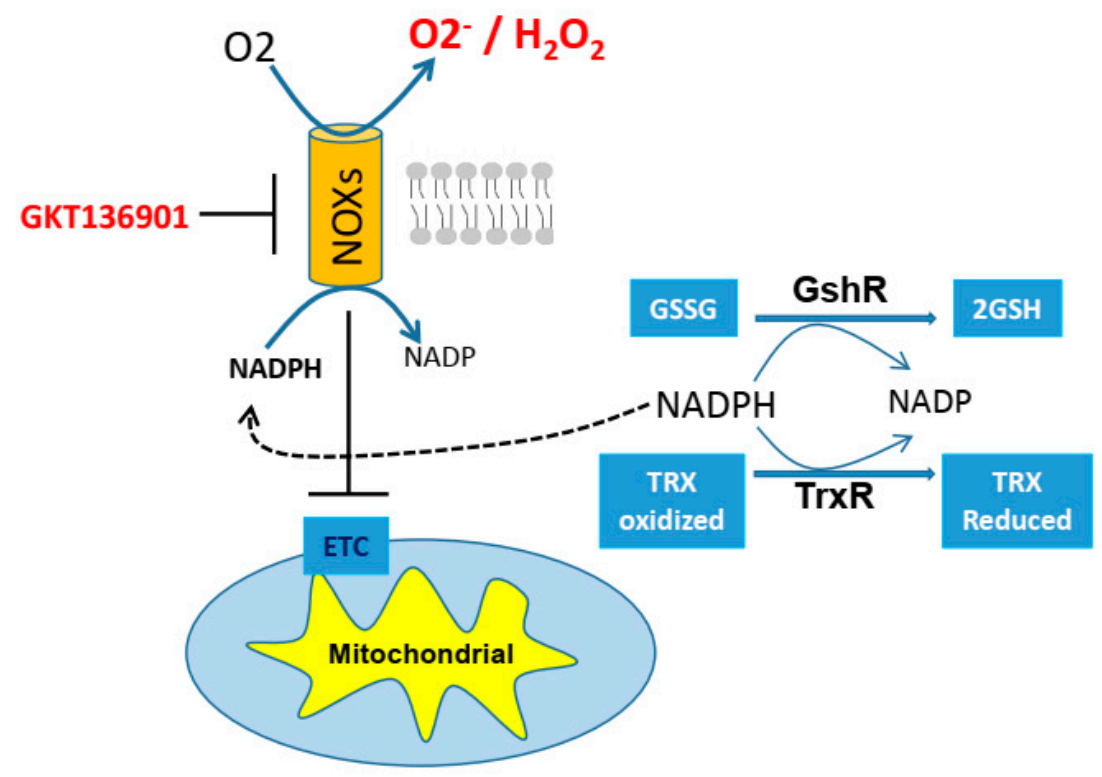

Figure 3. The dual role of NADPH. NADPH oxidase (NOX) can generate superoxide from oxygen and NADPH. On the other hand, NADPH is required for regeneration of GSH and TRX through glutathione reductase (GshR) and thioredoxin reductase (TrxR), respectively. ETC = electron transport chain, GSH = glutathione, GSSG = glutathione disulfide, NADPH = nicotinamide adenine dinucleotide phosphate, $\mathrm{NADP}=$ nicotinamide adenine dinucleotide phosphate, $\mathrm{TRX}=$ thioredoxin.

\subsection{Cisplatin Resistance and GSH/TRX Antioxidant Systems}

Numerous reports have shown that cisplatin targets thioredoxin reductase (TrxR), leading to increased intracellular ROS and resulting in growth arrest and subsequent cell death $[81,82]$. In order to adapt and survive at higher ROS levels and to avoid cell death caused by cisplatin, CR cells use less TRX and employ other antioxidant systems to compensate for the lack of TRX [83-85]. In fact, many have reported that CR cells have higher level of glutathione (GSH) proteins [86,87]. Lower intracellular TRX is due to protein degradation caused by cathepsin-D [88] or can be a consequence of increased TRX secretion, as we have reported [22]. TRX can be secreted via a special secretory pathway called the "leaderless pathway", which is known to secrete low molecular weight proteins that lack a signal peptide [89-91]. The mechanism of how this pathway functions remains poorly understood. Nevertheless, increased TRX secretion usually occurs when cells are under stress [92-94] and is detected in patients who received cisplatin treatment [95,96]. It is very likely that CR cells secrete higher amounts of TRX due to continuous cellular stress, which in turn results in lower intracellular accumulation of TRX and consequently increased ROS. Interestingly, studies showed that using TRX inhibitor (PX-12) can lower the elevated levels of plasma TRX in cancer patients, which can be used as surrogate indicator for the inhibition of tumor growth or proliferation [97]. More importantly, it is possible that augmented TRX levels can be reflected in serum samples prior to tumor progression by the RECIST criteria and hence may be used as early markers for disease progression.

As for the role of GSH in CR cells, it has been shown that pre-incubation with the GSH inhibitor buthionine sulfoximine (BSO) induces massive cell death, whereas N-acetyl cysteine, a precursor of glutathione synthesis, improves the resistance to cisplatin treatment [98]. However, targeting GSH should be done with caution, since a decade ago, depletion of GSH was not successful in increasing the antitumor effects of cisplatin in clinic due to the fact that GSH can also bind to platinum, which further complicates treatment [99]. It is noteworthy that chemotherapeutic agents generate ROS as one of the potent mechanisms to eradicate tumor cells; therefore, it is not surprising that targeting ROS by antioxidants has yielded mixed results in the therapeutic efficacy of chemotherapy [100]. 


\subsection{Cisplatin Resistance and NAD+}

Nicotinamide adenine dinucleotide (NAD+) is a crucial co-enzyme of all organisms' redox systems and is involved in many signaling pathways including cellular metabolism and DNA repair. In tumor cells, LDHA converts pyruvate to lactate and thereby generating NAD+, which will subsequently be reduced to NADH and used in glycolysis again (Figure 2). Thus, anaerobic glycolysis in cancer cells is dependent on NAD+. Moreover, $\mathrm{NAD+}$ is also used as the precursor to generate NADP+ via NAD kinase (NADK) [101]. In its reduced form (NADPH), this molecule maintains and regenerates cellular detoxifying and antioxidant oxidative defense systems as mentioned. As a result, it is undeniable that the level of NAD+ can influence cell homeostasis and survival. Significant alterations in NAD+ levels have been reported in renal tissue treated with cisplatin. In this study, they showed that cisplatin treatment resulted in a decrease of NAD+ in renal tissue without significant changes of NADH level [102], thus suggesting that the decrease in the $\mathrm{NAD+} / \mathrm{NADH}$ ratio by cisplatin is mainly caused by reduction of NAD+ levels. Therefore, it is possible that when cells became resistant to cisplatin, they adapted to survive under diminishing levels of NAD+. Our own findings that NAD+ levels are lower in CR cells are supported by other reports [6,103] and support the notion that CR cells undergo "second" metabolic reprograming and do not primarily depend on glycolysis.

The canonical role of NADPH oxidase (NOX) is to transport electrons across the plasma membrane, and in turn, to generate superoxide. The NOX family (i.e., NOX1, NOX4, etc.) is active in many important biological processes, including host defense, redox signaling, gene regulation, and post translation modifications [104,105]. Consumption of NAD+ by NOX in various cancer cells may also attenuate regeneration of TRX and GSH, thereby initiating an accumulation of intracellular ROS [106] (Figure 3). In addition, NOX may interfere with electron transport and affect ATP synthesis in mitochondria via activation of $\mathrm{PKC} \varepsilon$, mitoKATP, or modulation of mitochondria-thioredoxin activity [107]. Hence, it is possible that increased NOX can lead to "second" metabolic alterations that in turn lead to cisplatin resistance. In fact, it has been shown that NOX4 contributes to cisplatin resistance in renal cancer cells by modulation of pro-apoptotic and anti-apoptotic signaling, suggesting that NOX4 inhibition might enhance the efficacy of conventional cytotoxic drugs against renal cancers [80]. Additional support for a role in CR cell survival and tumor growth has been reported by others, who identified NOX4 as a critical downstream effector of inositol-trisphosphate 3-kinase B (ITP3K), a proliferative signal [108]. Therefore, targeting NOX4 could be used as an additional therapeutic agent to overcome resistance to cisplatin in future treatment.

\section{Cancer Cells and NAD+/PARP-1/SIRTs Axis}

Poly (ADP-ribose) polymerase 1 (PARP-1) and sirtuin (SIRT) are NAD+ dependent enzymes, and their interactions intertwine with cellular metabolism as well as the oxidative stress response. PARP-1 polymerizes ADP-ribose from NAD+ to the target protein, resulting in the formation of poly (ADP-ribose) or PAR, thus making PARP one of the major consumers of NAD+ $[109,110]$. Because PAR is negatively charged and noncovalently couples with nuclear proteins, PAR can act as a scaffolding for chromatin remodeling and DNA repair processes [111]. As for DNA damage repair, PARP-1 itself is its own target protein and is subjected to self-ribosylation (self-PAR) [112]. The synthesis and accumulation of a PAR chain then results in the recruitment of DNA repair scaffold enzymes (Figure 4, left panel). Ultimately, the activity of DNA ligase repairs DNA breaks. SIRTs also utilize NAD+ as a cofactor for their enzymatic activity. SIRTs have the dual role of protein modifications via deacetylation and ribosylation (Figure 4, right panel), which can lead to direct activation or inhibition of target transcriptional regulators as well as to the modification of their interaction profiles. 
A

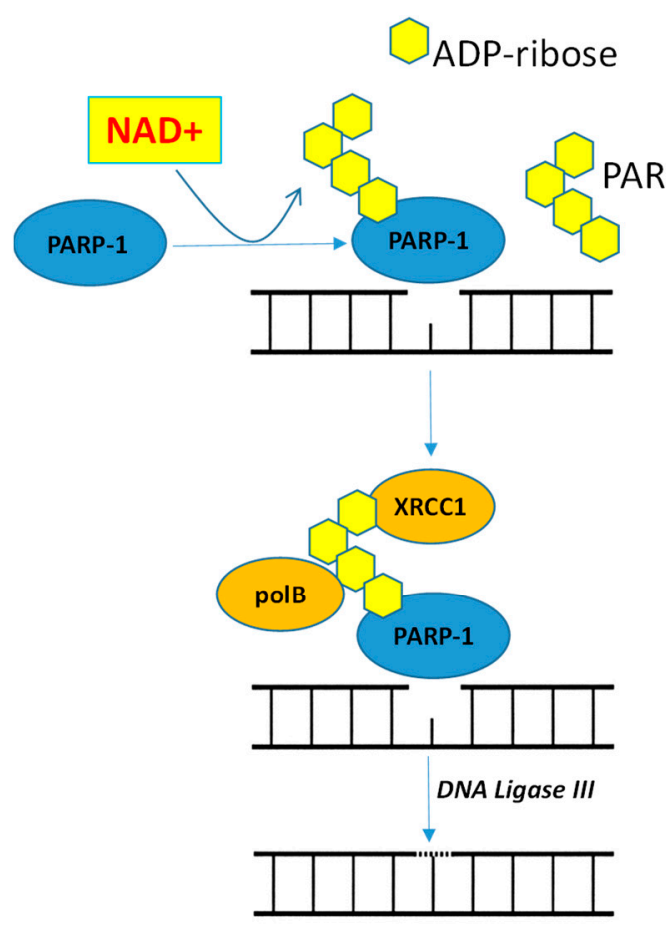

B

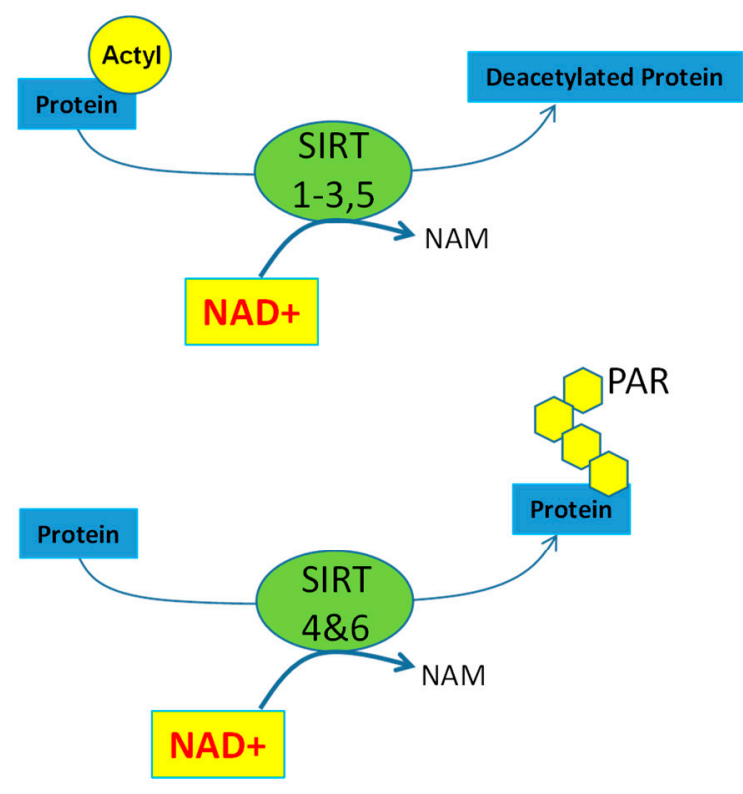

Figure 4. Panel (A) shows the role of PARP-1 in DNA base excision repair. PARP-1 binds to the damaged DNA and consumes nicotinamide adenine dinucleotide (NAD+) as a substrate to produce linear and branched polymers of ADP-ribose chain (PAR). PAR amplifies nucleosome remodeling by increasing the accessibility of base excision repair (BER) proteins such as X-ray repair cross-complementing protein 1 (XRCC1), DNA ligase III, and DNA polymerase $\beta$ (pol $\beta$ ) to the damaged DNA. Panel (B) indicates two reactions catalyzed by sirtuins: (i) deacetylation and (ii) ADP-ribosylation. SIRT1-SIRT3 and SIRT5 catalyze a deacetylation reaction in which an acetyl group is transferred to the ADP-ribose (ADPR) moiety of NAD+. In contrast, SIRT4 and SIRT6 catalyze ADP-ribosylation of proteins rather than deacetylation. ADP = Adenosine di-phosphate, $\mathrm{NAM}=$ nicotinamide PARP $=$ poly $(\mathrm{ADP}$-ribose $)$ polymerase $1, \mathrm{SIRT}=$ sirtuin .

The interaction between PARP-1 and SIRT is exclusively regulated by cellular NAD+ levels. It has been known that the decrease of NAD+-enhanced PARP activity correlates with a downregulation of SIRT activity [113]. Similarly, the activation of SIRT reduces PARP activity [114]. Thus, the pharmacological intervention to modulate PARP-1 and SIRT enzymes is possible but requires further understanding in CR tumors because CP induces DNA damage.

\subsection{Cisplatin Resistance and PARP-1}

Poly (ADP-ribose) (PAR) and the PAR polymerase-1 (PARP-1) play a key role in maintaining DNA integrity in the cells. Using NAD+ as a substrate, PARP-1 repeatedly catalyzes the transfer of successive units of ADP-ribose moieties, via a unique $2^{\prime}, 1^{\prime \prime}$-O-glycosidic ribose-ribose bond, to target proteins, finally producing the PAR chain [115]. With low levels of DNA damage, PARP-1 acts as a survival factor involved in DNA damage detection and repair. In contrast, with high levels of DNA damage, increased accumulation of PARP-1 promotes cell death. In the DNA base excision repair process, damaged bases are recognized by DNA glycosylase and are removed by cleavage of an N-glycosidic bond. Apurinic/apyrimidinic (AP) endonuclease cleaves the DNA backbone, thereby generating a single-strand DNA nick. PARP-1 recognizes the DNA nick as a single-strand break and facilitates poly ADP-ribosylation of target proteins. PARP-1 is subjected to self-assembly ADP-ribosylation (PAR) and binds to the X-ray repair cross-complementing 1 molecule (XRCC1) at the site of the single-strand DNA break [116]. XRCC1 interacts with DNA polymerase II (polB) and DNA ligase III that fills the DNA gap and completes the repair process, respectively (Figure 4, left panel). Consistent with the notion that PARP-1 plays an 
important role in mediating DNA repair, a majority of CR cells are dependent on PARP-1 and become susceptible to PARP inhibitor-induced apoptosis [117]. Recent reports showed that ovarian cancer cells that acquired CR expressed high levels of mitogen-activated protein kinase phosphatase-1 (MKP-1) and PARP-1 proteins; hence, silencing MKP-1 or PARP-1 increases cisplatin sensitivity in resistant cells. Moreover, the pharmacologic inhibition of PARP-1 activity restores cisplatin sensitivity in MKP-1 overexpressing cells [118]. PARP-1 knockout mice show increased mitochondrial numbers and oxygen consumption in a manner that mirrored SIRT1 activation [119]. Hence, removing PARP-1 as an enzyme that consumes NAD+ results in increased NAD+, SIRT1 activity, and OXME, thus linking the pathway involved in DNA repair to metabolic modulations in cells.

\subsection{Cisplatin Resistance and SIRTs}

The sirtuin family are NAD+-dependent histone deacetylases and ribosylases comprised of seven proteins denoted as SIRT1-7, which share a highly conserved NAD+binding catalytic domain [120]. SIRTs are involved in diverse cellular processes including DNA repair, redox, and energy metabolism. Interestingly, it has been shown that increased SIRT1 can lead to an increase in the $\mathrm{xCT}$ pump and confer resistance to cisplatin in ovarian cancer cells [121]. In addition, SIRT1 overexpression significantly enhanced the resistance to cisplatin and paclitaxel in endometrial carcinoma cell lines, thus using the SIRT1 inhibitor (EX527) to suppress the proliferation of these cells [122]. SIRT2 can inhibit lipid synthesis by suppressing ATP citrate lyase (ACLY) [123]. ATP citrate lyase is the primary enzyme responsible for the synthesis of cytosolic acetyl-CoA (Figure 2). Studies have shown that downregulation of SIRT2 decreased the sensitivity to cisplatin treatment in NSCLC, but on the other hand, upregulating SIRT2 by resveratrol treatment sensitized NSCLC cells to cisplatin treatment [124]. As for SIRT3, it has been shown that it may associate with glutamine metabolism and augment the activity of GDH (glutamate dehydrogenase) [125]. In cultured human tubular cells, cisplatin reduced SIRT3 expression, resulting in mitochondrial fragmentation, but restoration of SIRT3 with AICAR (AMPK agonist) improved cisplatin-induced mitochondrial dysfunction. Thus, these data indicate that enhancing SIRT3 can improve mitochondrial dynamics as a potential strategy for improving outcomes of renal injury caused by cisplatin [126]. Unlike SIRT3, SIRT4 inhibited GDH and was shown to protect against the accumulation of DNA damage and reduced cell death in DNA damage caused by cisplatin $[127,128]$. Reports also indicated that SIRT4 reduced pyruvate dehydrogenase complex (PDH) activity (an enzyme converting pyruvate to acetyl CoA for TCA cycle; see Diagram1) [129]. SIRT5 is overexpressed in human NSCLC and served as a predictor of poor prognosis. SIRT5 regulates lung cancer resistance to cisplatin, 5-FU, and bleomycin in vitro and in vivo through regulating Nrf2 and its downstream genes [130]. SIRT6 promotes DNA repair under stress by activating PARP-1, also playing a critical role in glucose homeostasis [131]. In the case of gluconeogenesis, SIRT6 indirectly suppresses PGC-1 $\alpha$, leading to downregulation of hepatic glucose production [132]. Similar to SIRT1, SIRT6 can function as a repressor of the transcription factor Hif1 $\alpha$ (a critical regulator of nutrient stress responses) and can shut down the glycolytic flux by deacetylation of histone H3 lysine 9 (H3K9) [133,134]. In contrast to SIRT3, increased SIRT7 levels result in increased expression of tumor necrosis factor- $\alpha$ (TNF- $\alpha$ ), which in turn stimulates ROS production through NOX2 [135]. Furthermore, SIRT7 knockout mice were resistant to cisplatin-induced renal injury. These extensive findings demonstrate that alteration in the expression of the SIRT family of proteins is one of several modifications that contribute to cellular resistance to cisplatin and suggest that regulation of SIRTs might be an important target for therapy and might serve as a potential prognostic factor.

\section{Cancer Cell and Immunometabolism}

New forms of cancer therapy using the body's own immune system to fight cancer have emerged lately. In particular, checkpoint inhibitor(s) such as nivolumab and pembrolizumab are FDA-approved agents. Moreover, increasing evidence suggests that 
downregulation of cellular metabolism plays a pivotal role in reducing the ability of the immune system to inhibit tumor growth. In the tumor microenvironment (TME), immune cells operate at a metabolic disadvantage since they are constrained by a lack of carbon nutrients due to the competition from the tumor cells [136]. In fact, we found that CR tumors undergo a "second" metabolic switch that utilized oxidative metabolism (OXMET) and increased amino acid uptake [6]. Consequently, this surrounding microenvironment is deprived of amino acids, creating an unfavorable condition for the viability of cytotoxic effector T cells ( $T$ eff), which are highly anabolic and require high amounts of amino acids for growth $[137,138]$. For instance, metabolite by-products of tryptophan catabolism such as kynurenine can inhibit $\mathrm{T}$ cell activation as well as cytolytic function and support immune suppressive regulatory T cell (T reg) differentiation [139]. HIF1 $\alpha$ induced by TME hypoxia can also promote the generation and maintenance of T reg cells [140]. Moreover, HIF1 $\alpha$ can also lead to the expression of programmed death ligand 1 (PD-L1) in myeloidderived suppressor cells (MDSC), thereby mediating potent immunosuppressive functions in tumor-specific $\mathrm{T}$ eff cells [141]. Together, the metabolic and nutrient changes found in $\mathrm{CR}$ tumors can reshape TME and have a decisive role in immune functions.

\subsection{CR Cells and PD-L1}

Programmed death 1 (PD-1, CD279) and its ligand PD-L1 (CD274) are transmembrane proteins. PD-1 is predominantly expressed in activated T cells while PD-L1 is known to be expressed in many cancer cells. PD-1 and PD-L1 engagement dampens T effector cells function, which leads to impairment of effective immune response against the tumor; thus, overexpression of PD-L1 has been correlated with poor prognosis in NSCLC [142]. Importantly, reports indicated that cisplatin treatment can induce PD-L1 expression in various cancer types, including NSCLC [143]. The specific mechanisms of this activation pathway are still not clearly defined. Nevertheless, it has been shown that ERK and AKT signaling pathways can induce upregulation of PD-L1 in both antigen presenting cells and cancer cells through STAT3 [144]. STAT3 has been implicated in regulating the TME through several mechanisms, including the recruitment of myeloid-derived suppressor cells (MDSCs) or the decrease of immune cell infiltration in different types of tumors. When activated, STAT3 undergoes phosphorylation-induced homodimerization. The homodimer then translocates to the nucleus and binds to a PD-L1 promoter. STAT3 also activates DNA methyltransferase-1 (DNMT1), which methylates the promoter region and subsequently suppresses the expression of genes involved in immune surveillance, such as immunoproteasome subunits (PSM) B8 and B9 and the human leukocyte antigens (HLA) [145]. Consistent with this finding, it has been demonstrated that abrogation of DNMT1 can decrease PD-L1 expression and increase cisplatin sensitivity [146].

NSCLC possess a higher baseline of PD-L1, but a recent finding has shown that NSCLC is resistant to cisplatin and undergoes epithelial-mesenchymal transition to enable invasion/metastasis as well as to escape immune surveillance by expressing even higher PD-L1. Thus, it is possible that monotherapy with immune checkpoint inhibitors that do not demonstrate encouraging results as first-line therapy may be better used for CR cells instead. In addition, the relationship between STAT3 and PD-L1 expression in CR tumors also provides evidence that STAT3 can be used as a predictive response to immunotherapy, which warrants further investigation.

\subsection{CR Cells and Kynurenine Pathway}

The impact of tumor metabolism on the tumor microenvironment is not well understood. Given the fact that NAD+ is very important for cell survival, it is known that tryptophan (TRP) can be used for de novo biosynthesis of NAD+ through the kynurenine pathway to quinolinic acid. This is the universal metabolite in biology that generates the aromatic pyridine ring of NAD+ [147]. However, TRP is less efficient and a poor NAD+ precursor in vivo. TRP will only be diverted to the synthesis of NAD+ when its supply exceeds enzymatic capacity [148]. Thus, the main source of NAD+ comes from salvage 
pathways, which require the uptake of other NAD+ precursors, such as nicotinic acid (NA). In fact, NA is 60 times more efficient as a precursor of NAD+ when compared with TRP $[149,150]$. TRP is an essential amino acid, required for protein synthesis, and as the precursor of serotonin and melatonin, the catabolism of TRP is known to generate kynurenine (KYN) via the kynurenine pathway. Approximately 99\% of ingested TRP not used for protein synthesis is catabolized by this pathway [151]. Importantly, indoleamine 2,3-dioxygenase (IDO; the rate-limiting step of the kynurenine pathway) can exploit superoxide as a substrate [152] and can in turn break down TRP, leading to the accumulation of KYN metabolites. Secretion of KYN to the tumor microenvironment plays a key role in reprogramming naïve $\mathrm{T}$ cells to the immune suppressive regulatory $\mathrm{T}$ cell $(\mathrm{T}$ reg) phenotype (Figure 5). Hence, these effects link tumor metabolism to the immune response localized to the tumor.

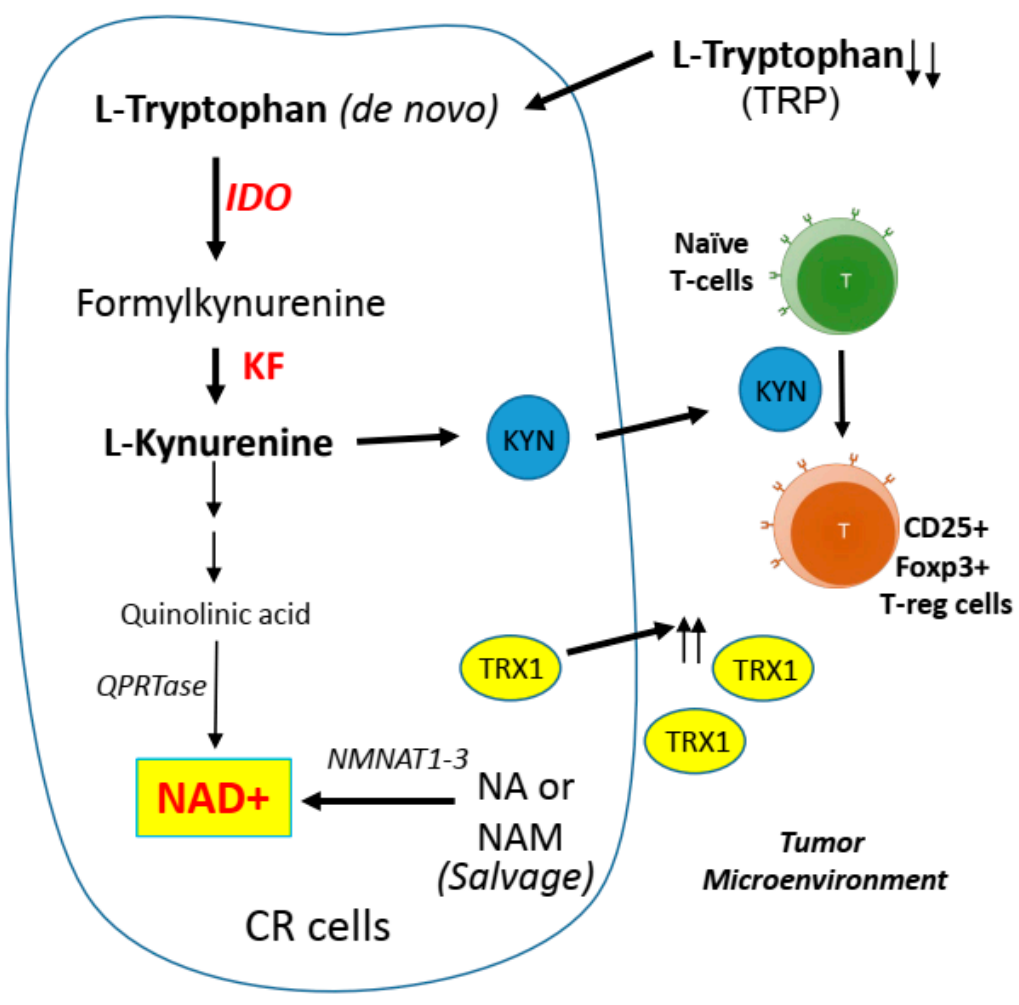

Figure 5. Schematic of tryptophan catabolism via the kynurenine pathway. Indoleamine 2,3dioxygenase (IDO) plays a key role in the regulation of the immune system. Increased kynurenine $(\mathrm{KYN})$ and thioredoxin-1 (TRX1) secretion from cisplatin resistant (CR) cells further enhances expansion of the regulatory $\mathrm{T}$ cell $(\mathrm{T}$ reg) population. $\mathrm{KF}=$ kynurenine formamidase, $\mathrm{NA}=$ nicotinic acid, NAM= nicotinamide (NAM), NMNAT = nicotinamide mononucleotide adenylyltransferase $1-3$, QPRTase = quinolinate phosphoribosyltransferase.

Interestingly, increased secretion of TRX1 from redox-stress and KYN levels in the TME can enhance regulatory $\mathrm{T}$ cell ( $\mathrm{T}$ reg) infiltration and stimulate the conversion of naive $T$ cells to $T$ reg [153-155], creating an immunosuppressive environment. These factors in combination with challenging nutrient availability contribute to a unique microenvironment that favors the presence of $\mathrm{T}$ reg rather than cytotoxic $\mathrm{T}$ cells. Higher basal levels of KYN have been found in multidrug-resistant cells than in chemo-sensitive cells, and these higher levels have also displayed an inverse correlation with patient survival $[156,157]$. There are preclinical findings that IDO1 inhibitors may be able to safely empower the efficacy of cytotoxic or targeted chemotherapy, radiotherapy, and immune checkpoint therapy. However, the recent ECHO-301/KEYNOTE-252 phase III clinical trial (NCT02752074) tested the efficacy of IDO1 inhibitor with other chemotherapy in patients with advanced melanoma previously untreated with PD-1 or PD-L1 checkpoint inhibitors 
and did not yield very satisfactory results [158]. The study did not meet its primary objective of improvement in progression-free survival [159]. The reasons for this negative trial are undefined, but it is possible that patient selection maybe the culprit, suggesting that IDO1 inhibitors should be used in patients who have already failed chemotherapy such as cisplatin.

\section{Concluding Remarks}

Cisplatin therapy for the treatment of solid tumors has many different uses and multiple cellular targets that are still not well defined. The well-accepted mechanism of induced cell death is through the formation of DNA adducts and increased oxidative stress. The development of platinum resistance is inevitable and complex, involving many molecular pathways. Given the revival that tumor Cell Metab. has seen in recent years as a target for therapeutic intervention in cancer, there is a growing appreciation that tumors undergo a "second" metabolic switch when acquiring resistance to cisplatin. Alterations in metabolic pathways therefore create a window of selectivity for these resistant cells. A new paradigm establishing effective connections between tumor metabolism and tumor microenvironment is gaining traction but is still in a very early stage of elucidation. The major concern is that most metabolic and redox studies are primarily performed in cultured cancer cells, which may not accurately represent the metabolic and redox status of intact tumors or of immune cells.

We still have limited knowledge of how and to what extent metabolic rewiring causes drug resistance in solid tumors, but emerging data that we reviewed herein are promising and may lead to rational combinations of metabolic drugs with chemotherapeutic agents (Table 1) that could improve treatment outcomes. We also believe that targeting tumor metabolism and the proximal microenvironment in patients who fail cisplatin should lead to improvement of overall survival.

Table 1. Example of potential metabolic targets for cancer therapy.

\begin{tabular}{|c|c|c|}
\hline Drug Name & Target (Propose Target) & References \\
\hline \multicolumn{3}{|c|}{ Glycolysis pathway } \\
\hline $2-\mathrm{DG}$ & HK & {$[160,161]$} \\
\hline FX-11 & LDHA & [6] \\
\hline Oxamate & LDHA & [162] \\
\hline DCA & PDK & {$[163]$} \\
\hline Riluzole & LDHA via NAD+ & {$[6,164]$} \\
\hline \multicolumn{3}{|c|}{ Glutaminolysis pathway } \\
\hline BPTES & GLS & [165] \\
\hline CB-839 & GLS & {$[166,167]$} \\
\hline EGCG & $\mathrm{GDH}$ & {$[168,169]$} \\
\hline \multicolumn{3}{|c|}{ Fatty acid synthesis pathway } \\
\hline C75 & FASN & {$[22,170,171]$} \\
\hline Cerulenin & FASN & [171] \\
\hline Orlistat & FASN & {$[171,172]$} \\
\hline TOFA & $\mathrm{ACC}$ & {$[22,171]$} \\
\hline \multicolumn{3}{|c|}{ Arginine synthesis pathway } \\
\hline ADI-PEG20 & arginine degradation & {$[54,173,174]$} \\
\hline Arginase1 & arginine degradation & {$[51,175]$} \\
\hline \multicolumn{3}{|c|}{ Redox pathway } \\
\hline $\mathrm{BSO}$ & GSH & {$[100,176,177]$} \\
\hline PX-12 & TRX & [178] \\
\hline Elesclomol & $\operatorname{ETC}(\mathrm{Cu}++)$ & {$[22,88,179]$} \\
\hline Riluzole & $\mathrm{xCT}$ & {$[6,164]$} \\
\hline SSZ & xCT & {$[43,180]$} \\
\hline EX527 & SIRT1 & [122] \\
\hline
\end{tabular}


Table 1. Cont.

\begin{tabular}{ccc}
\hline Drug Name & Target (Propose Target) & References \\
\hline Kynurenine pathway & & \\
\hline BCH & LAT1 & {$[173,174]$} \\
CH-223191 & AHR & {$[181]$} \\
Epacadostat & IDO & {$[176]$} \\
Indoximod & IDO & {$[176]$} \\
Navoximod & IDO & {$[176]$} \\
\hline
\end{tabular}

Author Contributions: M.W. and G.T. wrote this review. D.J.M.N. and C.W. prepared table figures. D.J.M.N., S.A.S., and L.G.F. proofread and organized the manuscript. N.S. edited this review. All authors have read and agreed to the published version of the manuscript.

Funding: This work is supported by BLR\&D Career Development Award-2 (1K2BX001289) and Merit Review Award (1I01BX004371) to M.W.; by the National Cancer Institute (1R01CA152197) and BLR\&D Merit Review Award (1BX003328) to N.S.

Institutional Review Board Statement: Patients undergoing cisplatin treatment were recruited in our study at the Miami VA Healthcare System. All procedures were approved by the Institution Review Board (IRB; ref.no.1190748-1). Participants prospectively provided informed consent for the use of their specimen in research.

Informed Consent Statement: Informed consent was obtained from all subjects involved in the study.

Data Availability Statement: All data are provided in the manuscript.

Conflicts of Interest: The authors declare no conflict of interest.

$\begin{array}{ll}\text { Abbreviations } \\ \text { ADI-PEG20 } & \text { Pegylated arginine deiminase } \\ \text { ACC } & \text { Acetyl-CoA Carboxylase } \\ \text { ACLY } & \text { ATP citrate lyase } \\ \text { AMPK } & \text { AMP-activated protein kinase } \\ \text { AP } & \text { Apurinic/apyrimidinic } \\ \text { ASS1 } & \text { Argininosuccinate synthetase-1 } \\ \text { BSO } & \text { Buthionine sulfoximine } \\ \text { DCA } & \text { Dichloroacetate } \\ \text { ETC } & \text { Electron transport chain } \\ \text { FASN } & \text { Fatty acid synthase } \\ \text { G-6-P } & \text { Glucose-6-phosphate } \\ \text { G6PDH } & \text { Glucose-6-phosphate dehydrogenase } \\ \text { GSH } & \text { Glutathione } \\ \text { GshR } & \text { GSH reductase } \\ \text { GSSG } & \text { Glutathione disulfide } \\ \text { GLS } & \text { Glutaminase } \\ \text { GLUT } & \text { Glucose transporter } \\ \text { H2O2 } & \text { Hydrogen Peroxide } \\ \text { HK } & \text { Hexokinase } \\ \text { IDO } & \text { Indoleamine 2,3-dioxygenase } \\ \text { ITP3K } & \text { Inositol-trisphosphate 3-kinase B } \\ \text { KYN } & \text { Kynurenine } \\ \text { LDHA } & \text { Lactate dehydrogenase A } \\ \text { mitoKATP } & \text { ATP-sensitive potassium channel from the inner mitochondrial membrane } \\ \text { MKP-1 } & \text { Mitogen-activated protein kinase phosphatase-1 } \\ \text { NAD } & \text { Nicotinamide adenine dinucleotide } \\ \text { NADPH } & \text { Nicotinamide adenine dinucleotide phosphate } \\ & \end{array}$




$\begin{array}{ll}\text { NMNAT1-3 } & \text { Nicotinamide mononucleotide adenylyltransferase 1-3 } \\ \text { NOX } & \text { NADPH oxidase } \\ \text { OXMET } & \text { Oxidative metabolism } \\ \text { PARP-1 } & \text { Poly (ADP ribose) polymerase 1 } \\ \text { PDH } & \text { Pyruvate dehydrogenase } \\ \text { PDK } & \text { Pyruvate dehydrogenase kinase } \\ \text { PKC } \varepsilon & \text { Protein kinase C epsilon type } \\ \text { PKM2 } & \text { Pyruvate kinase isozymes M2 } \\ \text { PPP } & \text { Pentose phosphate pathway } \\ \text { RECIST } & \text { Response evaluation criteria in solid tumors } \\ \text { ROS } & \text { Reactive oxygen species } \\ \text { SIRT } & \text { Sirtuin } \\ \text { SSZ } & \text { Sulfasalazine } \\ \text { T reg } & \text { Regulatory T cell } \\ \text { TCA } & \text { Tricarboxylic acid cycle } \\ \text { TME } & \text { Tumor microenvironment } \\ \text { TRP } & \text { Tryptophan } \\ \text { TRX } & \text { Thioredoxin } \\ \text { TrxR } & \text { TRX reductase } \\ \text { xCT } & \text { Cystine-glutamate exchange transporter, system } x_{\mathrm{c}}^{-} \\ \text {XRCC1 } & \text { X-ray repair cross-complementing 1 }\end{array}$

\section{References}

1. Rosenberg, B.; Vancamp, L.; Krigas, T. Inhibition of Cell Division in Escherichia Coli by Electrolysis Products from a Platinum Electrode. Nature 1965, 205, 698-699. [CrossRef] [PubMed]

2. Rosenberg, B.; VanCamp, L. The successful regression of large solid sarcoma 180 tumors by platinum compounds. Cancer Res. 1970, 30, 1799-1802.

3. Cohen, S.M.; Lippard, S.J. Cisplatin: From DNA damage to cancer chemotherapy. Prog. Nucleic Acid Res. Mol. Biol. 2001, 67, 93-130. [PubMed]

4. Siddik, Z.H. Cisplatin: Mode of cytotoxic action and molecular basis of resistance. Oncogene 2003, 22, 7265-7279. [CrossRef]

5. Vander Heiden, M.G.; Cantley, L.C.; Thompson, C.B. Understanding the Warburg effect: The metabolic requirements of cell proliferation. Science 2009, 324, 1029-1033. [CrossRef] [PubMed]

6. Wangpaichitr, M.; Wu, C.; Li, Y.Y.; Nguyen, D.J.M.; Kandemir, H.; Shah, S.; Chen, S.; Feun, L.G.; Prince, J.S.; Kuo, M.T.; et al Exploiting ROS and metabolic differences to kill cisplatin resistant lung cancer. Oncotarget 2017, 8, 49275-49292. [CrossRef] [PubMed]

7. Zaal, E.A.; Berkers, C.R. The Influence of Metabolism on Drug Response in Cancer. Front. Oncol. 2018, 8, 500. [CrossRef]

8. Marullo, R.; Werner, E.; Degtyareva, N.; Moore, B.; Altavilla, G.; Ramalingam, S.S.; Doetsch, P.W. Cisplatin induces a mitochondrial-ROS response that contributes to cytotoxicity depending on mitochondrial redox status and bioenergetic functions. PLoS ONE 2013, 8, e81162. [CrossRef]

9. Warburg, O. On the origin of cancer cells. Science 1956, 123, 309-314. [CrossRef]

10. Warburg, O. On respiratory impairment in cancer cells. Science 1956, 124, 269-270.

11. Kurtoglu, M.; Maher, J.C.; Lampidis, T.J. Differential toxic mechanisms of 2-deoxy-D-glucose versus 2-fluorodeoxy-D-glucose in hypoxic and normoxic tumor cells. Antioxid. Redox Signal. 2007, 9, 1383-1390. [CrossRef] [PubMed]

12. Geschwind, J.F.; Georgiades, C.S.; Ko, Y.H.; Pedersen, P.L. Recently elucidated energy catabolism pathways provide opportunities for novel treatments in hepatocellular carcinoma. Expert Rev. Anticancer Ther. 2004, 4, 449-457. [CrossRef] [PubMed]

13. Sajnani, K.; Islam, F.; Smith, R.A.; Gopalan, V.; Lam, A.K. Genetic alterations in Krebs cycle and its impact on cancer pathogenesis. Biochimie 2017, 135, 164-172. [CrossRef]

14. Cardaci, S.; Ciriolo, M.R. TCA Cycle Defects and Cancer: When Metabolism Tunes Redox State. Int. J. Cell Biol. 2012, $2012,161837$. [CrossRef]

15. Sulkowski, P.L.; Sundaram, R.K.; Oeck, S.; Corso, C.D.; Liu, Y.; Noorbakhsh, S.; Niger, M.; Boeke, M.; Ueno, D.; Kalathil, A.N.; et al. Krebs-cycle-deficient hereditary cancer syndromes are defined by defects in homologous-recombination DNA repair. Nat. Genet. 2018, 50, 1086-1092. [CrossRef] [PubMed]

16. Hanahan, D.; Weinberg, R.A. Hallmarks of cancer: The next generation. Cell 2011, 144, 646-674. [CrossRef] [PubMed]

17. Zhu, A.; Lee, D.; Shim, H. Metabolic positron emission tomography imaging in cancer detection and therapy response. Semin. Oncol. 2011, 38, 55-69. [CrossRef]

18. Song, I.S.; Savaraj, N.; Siddik, Z.H.; Liu, P.; Wei, Y.; Wu, C.J.; Kuo, M.T. Role of human copper transporter Ctr1 in the transport of platinum-based antitumor agents in cisplatin-sensitive and cisplatin-resistant cells. Mol. Cancer Ther. 2004, 3, $1543-1549$.

19. Kuo, M.T.; Chen, H.H.; Song, I.S.; Savaraj, N.; Ishikawa, T. The roles of copper transporters in cisplatin resistance. Cancer Metastasis Rev. 2007, 26, 71-83. [CrossRef] 
20. Chen, H.H.; Yan, J.J.; Chen, W.C.; Kuo, M.T.; Lai, Y.H.; Lai, W.W.; Liu, H.S.; Su, W.C. Predictive and prognostic value of human copper transporter 1 (hCtr1) in patients with stage III non-small-cell lung cancer receiving first-line platinum-based doublet chemotherapy. Lung Cancer 2011, 75, 228-234. [CrossRef]

21. Liang, X.J.; Finkel, T.; Shen, D.W.; Yin, J.J.; Aszalos, A.; Gottesman, M.M. SIRT1 contributes in part to cisplatin resistance in cancer cells by altering mitochondrial metabolism. Mol Cancer Res. 2008, 6, 1499-1506. [CrossRef]

22. Wangpaichitr, M.; Sullivan, E.J.; Theodoropoulos, G.; Wu, C.; You, M.; Feun, L.G.; Lampidis, T.J.; Kuo, M.T.; Savaraj, N. The relationship of thioredoxin-1 and cisplatin resistance: Its impact on ROS and oxidative metabolism in lung cancer cells. Mol. Cancer Ther. 2012, 11, 604-615. [CrossRef]

23. Wang, Y.; Zeigler, M.M.; Lam, G.K.; Hunter, M.G.; Eubank, T.D.; Khramtsov, V.V.; Tridandapani, S.; Sen, C.K.; Marsh, C.B. The role of the NADPH oxidase complex, p38 MAPK, and Akt in regulating human monocyte/macrophage survival. Am. J. Respir Cell Mol. Biol. 2007, 36, 68-77. [CrossRef]

24. Pan, M.H.; Ho, C.T. Chemopreventive effects of natural dietary compounds on cancer development. Chem. Soc. Rev. 2008, 37, 2558-2574. [CrossRef]

25. Sullivan, E.J.; Kurtoglu, M.; Brenneman, R.; Liu, H.; Lampidis, T.J. Targeting cisplatin-resistant human tumor cells with metabolic inhibitors. Cancer Chemother. Pharmacol. 2014, 73, 417-427. [CrossRef]

26. Vander Heiden, M.G.; Locasale, J.W.; Swanson, K.D.; Sharfi, H.; Heffron, G.J.; Amador-Noguez, D.; Christofk, H.R.; Wagner, G.; Rabinowitz, J.D.; Asara, J.M.; et al. Evidence for an alternative glycolytic pathway in rapidly proliferating cells. Science 2010, 329, 1492-1499. [CrossRef] [PubMed]

27. Yoo, B.C.; Ku, J.L.; Hong, S.H.; Shin, Y.K.; Park, S.Y.; Kim, H.K.; Park, J.G. Decreased pyruvate kinase M2 activity linked to cisplatin resistance in human gastric carcinoma cell lines. Int. J. Cancer 2004, 108, 532-539. [CrossRef]

28. Martinez-Balibrea, E.; Plasencia, C.; Gines, A.; Martinez-Cardus, A.; Musulen, E.; Aguilera, R.; Manzano, J.L.; Neamati, N.; Abad, A. A proteomic approach links decreased pyruvate kinase M2 expression to oxaliplatin resistance in patients with colorectal cancer and in human cell lines. Mol. Cancer Ther. 2009, 8, 771-778. [CrossRef]

29. Shin, Y.K.; Yoo, B.C.; Hong, Y.S.; Chang, H.J.; Jung, K.H.; Jeong, S.Y.; Park, J.G. Upregulation of glycolytic enzymes in proteins secreted from human colon cancer cells with 5-fluorouracil resistance. Electrophoresis 2009, 30, 2182-2192. [CrossRef]

30. Lu, W.Q.; Hu, Y.Y.; Lin, X.P.; Fan, W. Knockdown of PKM2 and GLS1 expression can significantly reverse oxaliplatin-resistance in colorectal cancer cells. Oncotarget 2017, 8, 44171-44185. [CrossRef]

31. Wang, X.; Zhang, F.; Wu, X.R. Inhibition of Pyruvate Kinase M2 Markedly Reduces Chemoresistance of Advanced Bladder Cancer to Cisplatin. Sci. Rep. 2017, 7, 45983. [CrossRef] [PubMed]

32. Kim, D.J.; Park, Y.S.; Kang, M.G.; You, Y.M.; Jung, Y.; Koo, H.; Kim, J.A.; Kim, M.J.; Hong, S.M.; Lee, K.B.; et al. Pyruvate kinase isoenzyme M2 is a therapeutic target of gemcitabine-resistant pancreatic cancer cells. Exp. Cell Res. 2015, 336, 119-129. [CrossRef] [PubMed]

33. Li, Q.; Zhang, D.; Chen, X.; He, L.; Li, T.; Xu, X.; Li, M. Nuclear PKM2 contributes to gefitinib resistance via upregulation of STAT3 activation in colorectal cancer. Sci. Rep. 2015, 5, 16082. [CrossRef]

34. Guo, W.; Zhang, Y.; Chen, T.; Wang, Y.; Xue, J.; Zhang, Y.; Xiao, W.; Mo, X.; Lu, Y. Efficacy of RNAi targeting of pyruvate kinase M2 combined with cisplatin in a lung cancer model. J. Cancer Res. Clin. Oncol. 2011, 137, 65-72. [CrossRef] [PubMed]

35. Shi, H.S.; Li, D.; Zhang, J.; Wang, Y.S.; Yang, L.; Zhang, H.L.; Wang, X.H.; Mu, B.; Wang, W.; Ma, Y.; et al. Silencing of pkm2 increases the efficacy of docetaxel in human lung cancer xenografts in mice. Cancer Sci. 2010, 101, 1447-1453. [CrossRef]

36. Hudson, C.D.; Savadelis, A.; Nagaraj, A.B.; Joseph, P.; Avril, S.; DiFeo, A.; Avril, N. Altered glutamine metabolism in platinum resistant ovarian cancer. Oncotarget 2016, 7, 41637-41649. [CrossRef]

37. DeBerardinis, R.J.; Lum, J.J.; Hatzivassiliou, G.; Thompson, C.B. The biology of cancer: Metabolic reprogramming fuels cell growth and proliferation. Cell Metab. 2008, 7, 11-20. [CrossRef]

38. Nicklin, P.; Bergman, P.; Zhang, B.; Triantafellow, E.; Wang, H.; Nyfeler, B.; Yang, H.; Hild, M.; Kung, C.; Wilson, C.; et al. Bidirectional transport of amino acids regulates mTOR and autophagy. Cell 2009, 136, 521-534. [CrossRef]

39. Jewell, J.L.; Kim, Y.C.; Russell, R.C.; Yu, F.X.; Park, H.W.; Plouffe, S.W.; Tagliabracci, V.S.; Guan, K.L. Metabolism. Differential regulation of mTORC1 by leucine and glutamine. Science 2015, 347, 194-198. [CrossRef]

40. Lo, M.; Wang, Y.Z.; Gout, P.W. The x(c)- cystine/glutamate antiporter: A potential target for therapy of cancer and other diseases. J. Cell Physiol. 2008, 215, 593-602. [CrossRef]

41. Shukla, K.; Thomas, A.G.; Ferraris, D.V.; Hin, N.; Sattler, R.; Alt, J.; Rojas, C.; Slusher, B.S.; Tsukamoto, T. Inhibition of xc(-) transporter-mediated cystine uptake by sulfasalazine analogs. Bioorg. Med. Chem. Lett. 2011, 21, 6184-6187. [CrossRef]

42. Evonuk, K.S.; Baker, B.J.; Doyle, R.E.; Moseley, C.E.; Sestero, C.M.; Johnston, B.P.; De Sarno, P.; Tang, A.; Gembitsky, I.; Hewett, S.J.; et al. Inhibition of System Xc(-) Transporter Attenuates Autoimmune Inflammatory Demyelination. J. Immunol. 2015, 195, 450-463. [CrossRef] [PubMed]

43. Ma, M.Z.; Chen, G.; Wang, P.; Lu, W.H.; Zhu, C.F.; Song, M.; Yang, J.; Wen, S.; Xu, R.H.; Hu, Y.; et al. Xc- inhibitor sulfasalazine sensitizes colorectal cancer to cisplatin by a GSH-dependent mechanism. Cancer Lett. 2015, 368, 88-96. [CrossRef] [PubMed]

44. Savaraj, N.; Wu, C.; Kuo, M.T.; You, M.; Wangpaichitr, M.; Robles, C.; Spector, S.; Feun, L. The relationship of arginine deprivation, argininosuccinate synthetase and cell death in melanoma. Drug Target Insights 2007, 2, 119-128. [CrossRef] [PubMed]

45. Ensor, C.M.; Holtsberg, F.W.; Bomalaski, J.S.; Clark, M.A. Pegylated arginine deiminase (ADI-SS PEG20,000 mw) inhibits human melanomas and hepatocellular carcinomas in vitro and in vivo. Cancer Res. 2002, 62, 5443-5450. [PubMed] 
46. Dillon, B.J.; Prieto, V.G.; Curley, S.A.; Ensor, C.M.; Holtsberg, F.W.; Bomalaski, J.S.; Clark, M.A. Incidence and distribution of argininosuccinate synthetase deficiency in human cancers: A method for identifying cancers sensitive to arginine deprivation. Cancer 2004, 100, 826-833. [CrossRef] [PubMed]

47. Szlosarek, P.W.; Klabatsa, A.; Pallaska, A.; Sheaff, M.; Smith, P.; Crook, T.; Grimshaw, M.J.; Steele, J.P.; Rudd, R.M.; Balkwill, F.R.; et al. In vivo loss of expression of argininosuccinate synthetase in malignant pleural mesothelioma is a biomarker for susceptibility to arginine depletion. Clin. Cancer Res. 2006, 12, 7126-7131. [CrossRef]

48. Liu, Q.; Stewart, J.; Wang, H.; Rashid, A.; Zhao, J.; Katz, M.H.; Lee, J.E.; Fleming, J.B.; Maitra, A.; Wolff, R.A.; et al. Reduced expression of argininosuccinate synthetase 1 has a negative prognostic impact in patients with pancreatic ductal adenocarcinoma. PLoS ONE 2017, 12, e0171985. [CrossRef]

49. Kim, Y.; Kobayashi, E.; Kubota, D.; Suehara, Y.; Mukaihara, K.; Akaike, K.; Ito, A.; Kaneko, K.; Chuman, H.; Kawai, A.; et al. Reduced argininosuccinate synthetase expression in refractory sarcomas: Impacts on therapeutic potential and drug resistance. Oncotarget 2016, 7, 70832-70844. [CrossRef]

50. Wei, S.H.; Chen, C.M.; Strathdee, G.; Harnsomburana, J.; Shyu, C.R.; Rahmatpanah, F.; Shi, H.; Ng, S.W.; Yan, P.S.; Nephew, K.P.; et al. Methylation microarray analysis of late-stage ovarian carcinomas distinguishes progression-free survival in patients and identifies candidate epigenetic markers. Clin. Cancer Res. 2002, 8, 2246-2252.

51. Long, Y.; Tsai, W.B.; Chang, J.T.; Estecio, M.; Wangpaichitr, M.; Savaraj, N.; Feun, L.G.; Chen, H.H.; Kuo, M.T. Cisplatin-induced synthetic lethality to arginine-starvation therapy by transcriptional suppression of ASS1 is regulated by DEC1, HIF-1alpha, and c-Myc transcription network and is independent of ASS1 promoter DNA methylation. Oncotarget 2016, 7, 82658-82670. [CrossRef] [PubMed]

52. Nicholson, L.J.; Smith, P.R.; Hiller, L.; Szlosarek, P.W.; Kimberley, C.; Sehouli, J.; Koensgen, D.; Mustea, A.; Schmid, P.; Crook, T. Epigenetic silencing of argininosuccinate synthetase confers resistance to platinum-induced cell death but collateral sensitivity to arginine auxotrophy in ovarian cancer. Int. J. Cancer 2009, 125, 1454-1463. [CrossRef]

53. Tsai, W.B.; Aiba, I.; Lee, S.Y.; Feun, L.; Savaraj, N.; Kuo, M.T. Resistance to arginine deiminase treatment in melanoma cells is associated with induced argininosuccinate synthetase expression involving c-Myc/HIF-1alpha/Sp4. Mol. Cancer Ther. 2009, 8, 3223-3233. [CrossRef] [PubMed]

54. Kuo, M.T.; Savaraj, N.; Feun, L.G. Targeted cellular metabolism for cancer chemotherapy with recombinant arginine-degrading enzymes. Oncotarget 2010, 1, 246-251. [CrossRef] [PubMed]

55. Feun, L.; Savaraj, N. Pegylated arginine deiminase: A novel anticancer enzyme agent. Expert Opin. Investig. Drugs 2006, 15, 815-822. [CrossRef]

56. Yau, T.; Cheng, P.N.; Chan, P.; Chen, L.; Yuen, J.; Pang, R.; Fan, S.T.; Wheatley, D.N.; Poon, R.T. Preliminary efficacy, safety, pharmacokinetics, pharmacodynamics and quality of life study of pegylated recombinant human arginase 1 in patients with advanced hepatocellular carcinoma. Invest. New Drugs 2015, 33, 496-504. [CrossRef] [PubMed]

57. Feun, L.G.; Kuo, M.T.; Savaraj, N. Arginine deprivation in cancer therapy. Curr. Opin. Clin. Nutr. Metab. Care 2015, 18, 78-82. [CrossRef]

58. Duan, J.; Sun, L.; Huang, H.; Wu, Z.; Wang, L.; Liao, W. Overexpression of fatty acid synthase predicts a poor prognosis for human gastric cancer. Mol. Med. Rep. 2016, 13, 3027-3035. [CrossRef]

59. Cai, Y.; Wang, J.; Zhang, L.; Wu, D.; Yu, D.; Tian, X.; Liu, J.; Jiang, X.; Shen, Y.; Zhang, L.; et al. Expressions of fatty acid synthase and HER2 are correlated with poor prognosis of ovarian cancer. Med. Oncol. 2015, 32, 391. [CrossRef]

60. Takahiro, T.; Shinichi, K.; Toshimitsu, S. Expression of fatty acid synthase as a prognostic indicator in soft tissue sarcomas. Clin. Cancer Res. 2003, 9, 2204-2212.

61. Uddin, S.; Jehan, Z.; Ahmed, M.; Alyan, A.; Al-Dayel, F.; Hussain, A.; Bavi, P.; Al-Kuraya, K.S. Overexpression of fatty acid synthase in Middle Eastern epithelial ovarian carcinoma activates AKT and Its inhibition potentiates cisplatin-induced apoptosis. Mol. Med. 2011, 17, 635-645. [CrossRef]

62. Carracedo, A.; Cantley, L.C.; Pandolfi, P.P. Cancer metabolism: Fatty acid oxidation in the limelight. Nat. Rev. Cancer 2013, 13, 227-232. [CrossRef]

63. Vazquez-Martin, A.; Colomer, R.; Brunet, J.; Menendez, J.A. Pharmacological blockade of fatty acid synthase (FASN) reverses acquired autoresistance to trastuzumab (Herceptin by transcriptionally inhibiting 'HER2 super-expression' occurring in high-dose trastuzumab-conditioned SKBR3/Tzb100 breast cancer cells. Int. J. Oncol. 2007, 31, 769-776. [CrossRef]

64. Menendez, J.A.; Vellon, L.; Lupu, R. The antiobesity drug Orlistat induces cytotoxic effects, suppresses Her-2/neu (erbB-2) oncogene overexpression, and synergistically interacts with trastuzumab (Herceptin) in chemoresistant ovarian cancer cells. Int. J. Gynecol. Cancer 2006, 16, 219-221. [CrossRef]

65. Liu, H.; Liu, Y.; Zhang, J.T. A new mechanism of drug resistance in breast cancer cells: Fatty acid synthase overexpressionmediated palmitate overproduction. Mol. Cancer Ther. 2008, 7, 263-270. [CrossRef]

66. Yang, Y.; Liu, H.; Li, Z.; Zhao, Z.; Yip-Schneider, M.; Fan, Q.; Schmidt, C.M.; Chiorean, E.G.; Xie, J.; Cheng, L.; et al. Role of fatty acid synthase in gemcitabine and radiation resistance of pancreatic cancers. Int. J. Biochem. Mol. Biol. 2011, 2, 89-98. [PubMed]

67. Warmoes, M.; Jaspers, J.E.; Xu, G.; Sampadi, B.K.; Pham, T.V.; Knol, J.C.; Piersma, S.R.; Boven, E.; Jonkers, J.; Rottenberg, S.; et al. Proteomics of genetically engineered mouse mammary tumors identifies fatty acid metabolism members as potential predictive markers for cisplatin resistance. Mol. Cell Proteom. 2013, 12, 1319-1334. [CrossRef] [PubMed] 
68. Kant, S.; Kumar, A.; Singh, S.M. Tumor growth retardation and chemosensitizing action of fatty acid synthase inhibitor orlistat on T cell lymphoma: Implication of reconstituted tumor microenvironment and multidrug resistance phenotype. Biochim. Biophys. Acta 2014, 1840, 294-302. [CrossRef]

69. Borst, P.; Evers, R.; Kool, M.; Wijnholds, J. The multidrug resistance protein family. Biochim. Biophys. Acta 1999, 1461, 347-357. [CrossRef]

70. Savaraj, N.; Wu, C.; Wangpaichitr, M.; Kuo, M.T.; Lampidis, T.; Robles, C.; Furst, A.J.; Feun, L. Overexpression of mutated MRP4 in cisplatin resistant small cell lung cancer cell line: Collateral sensitivity to azidothymidine. Int. J. Oncol. 2003, 23, 173-179. [CrossRef] [PubMed]

71. Preston, T.J.; Muller, W.J.; Singh, G. Scavenging of extracellular H2O2 by catalase inhibits the proliferation of HER-2/Neutransformed rat-1 fibroblasts through the induction of a stress response. J. Biol. Chem. 2001, 276, 9558-9564. [CrossRef]

72. Lillig, C.H.; Holmgren, A. Thioredoxin and related molecules-from biology to health and disease. Antioxid. Redox Signal. 2007, 9 , 25-47. [CrossRef] [PubMed]

73. Zhang, H.; Forman, H.J. Glutathione synthesis and its role in redox signaling. Semin. Cell Dev. Biol. 2012, 23, 722-728. [CrossRef] [PubMed]

74. Kaplan, J.C.; Beutler, E. Electrophoretic study of glutathione reductase in human erythrocytes and leucocytes. Nature 1968, 217, 256-258. [CrossRef]

75. Arner, E.S.; Holmgren, A. Physiological functions of thioredoxin and thioredoxin reductase. Eur. J. Biochem. 2000, 267, 6102-6109. [CrossRef]

76. Kirkman, H.N.; Gaetani, G.F. Catalase: A tetrameric enzyme with four tightly bound molecules of NADPH. Proc. Natl. Acad. Sci. USA 1984, 81, 4343-4347. [CrossRef]

77. Bedard, K.; Krause, K.H. The NOX family of ROS-generating NADPH oxidases: Physiology and pathophysiology. Physiol. Rev. 2007, 87, 245-313. [CrossRef]

78. Tanaka, M.; Miura, Y.; Numanami, H.; Karnan, S.; Ota, A.; Konishi, H.; Hosokawa, Y.; Hanyuda, M. Inhibition of NADPH oxidase 4 induces apoptosis in malignant mesothelioma: Role of reactive oxygen species. Oncol. Rep. 2015, 34, 1726-1732. [CrossRef] [PubMed]

79. Ushio-Fukai, M. Localizing NADPH oxidase-derived ROS. Sci. STKE 2006, 2006, re8. [CrossRef]

80. Chang, G.; Chen, L.; Lin, H.M.; Lin, Y.; Maranchie, J.K. Nox4 inhibition enhances the cytotoxicity of cisplatin in human renal cancer cells. J. Exp. Ther. Oncol. 2012, 10, 9-18.

81. Saitoh, M.; Nishitoh, H.; Fujii, M.; Takeda, K.; Tobiume, K.; Sawada, Y.; Kawabata, M.; Miyazono, K.; Ichijo, H. Mammalian thioredoxin is a direct inhibitor of apoptosis signal-regulating kinase (ASK) 1. Embo J. 1998, 17, 2596-2606. [CrossRef]

82. Sun, Y.; Rigas, B. The thioredoxin system mediates redox-induced cell death in human colon cancer cells: Implications for the mechanism of action of anticancer agents. Cancer Res. 2008, 68, 8269-8277. [CrossRef] [PubMed]

83. Witte, A.B.; Anestal, K.; Jerremalm, E.; Ehrsson, H.; Arner, E.S. Inhibition of thioredoxin reductase but not of glutathione reductase by the major classes of alkylating and platinum-containing anticancer compounds. Free Radic. Biol. Med. 2005, 39, 696-703. [CrossRef]

84. Mostert, V.; Hill, K.E.; Burk, R.F. Loss of activity of the selenoenzyme thioredoxin reductase causes induction of hepatic heme oxygenase-1. FEBS Lett. 2003, 541, 85-88. [CrossRef]

85. Lu, Y.; Cederbaum, A. The mode of cisplatin-induced cell death in CYP2E1-overexpressing HepG2 cells: Modulation by ERK, ROS, glutathione, and thioredoxin. Free Radic. Biol. Med. 2007, 43, 1061-1075. [CrossRef] [PubMed]

86. Wangpaichitr, M.; Wu, C.; You, M.; Maher, J.C.; Dinh, V.; Feun, L.G.; Savaraj, N. N1,N3-Dimethyl-N1,N3-bis(phenylcarbonothioyl) Propanedihydrazide (Elesclomol) Selectively Kills Cisplatin Resistant Lung Cancer Cells through Reactive Oxygen Species (ROS). Cancers 2009, 1, 23-28. [CrossRef] [PubMed]

87. Chen, H.H.; Kuo, M.T. Role of glutathione in the regulation of Cisplatin resistance in cancer chemotherapy. Met. Based Drugs 2010, 2010. [CrossRef]

88. Haendeler, J.; Popp, R.; Goy, C.; Tischler, V.; Zeiher, A.M.; Dimmeler, S. Cathepsin D and H2O2 stimulate degradation of thioredoxin-1: Implication for endothelial cell apoptosis. J. Biol. Chem. 2005, 280, 42945-42951. [CrossRef]

89. Rubartelli, A.; Bajetto, A.; Allavena, G.; Wollman, E.; Sitia, R. Secretion of thioredoxin by normal and neoplastic cells through a leaderless secretory pathway. J. Biol. Chem. 1992, 267, 24161-24164. [CrossRef]

90. Rubartelli, A.; Bajetto, A.; Bonifaci, N.; Di Blas, E.; Solito, E.; Sitia, R. A novel way to get out of the cell. Cytotechnology 1993, 11 (Suppl. S1), S37-S40. [CrossRef]

91. Rubartelli, A.; Bonifaci, N.; Sitia, R. High rates of thioredoxin secretion correlate with growth arrest in hepatoma cells. Cancer Res. 1995, 55, 675-680.

92. Miyamoto, S.; Kawano, H.; Sakamoto, T.; Soejima, H.; Kajiwara, I.; Hokamaki, J.; Hirai, N.; Sugiyama, S.; Yoshimura, M.; Yasue, H.; et al. Increased plasma levels of thioredoxin in patients with coronary spastic angina. Antioxid. Redox Signal. 2004, 6, 75-80. [CrossRef] [PubMed]

93. Nakamura, H.; De Rosa, S.; Roederer, M.; Anderson, M.T.; Dubs, J.G.; Yodoi, J.; Holmgren, A.; Herzenberg, L.A.; Herzenberg, L.A. Elevation of plasma thioredoxin levels in HIV-infected individuals. Int. Immunol. 1996, 8, 603-611. [CrossRef]

94. Nakamura, H.; Vaage, J.; Valen, G.; Padilla, C.A.; Bjornstedt, M.; Holmgren, A. Measurements of plasma glutaredoxin and thioredoxin in healthy volunteers and during open-heart surgery. Free Radic. Biol. Med. 1998, 24, 1176-1186. [CrossRef] 
95. Sasada, T.; Nakamura, H.; Ueda, S.; Iwata, S.; Ueno, M.; Takabayashi, A.; Yodoi, J. Secretion of thioredoxin enhances cellular resistance to cis-diamminedichloroplatinum (II). Antioxid. Redox Signal. 2000, 2, 695-705. [CrossRef] [PubMed]

96. Sasada, T.; Nakamura, H.; Ueda, S.; Sato, N.; Kitaoka, Y.; Gon, Y.; Takabayashi, A.; Spyrou, G.; Holmgren, A.; Yodoi, J. Possible involvement of thioredoxin reductase as well as thioredoxin in cellular sensitivity to cis-diamminedichloroplatinum (II). Free Radic. Biol. Med. 1999, 27, 504-514. [CrossRef]

97. Baker, A.F.; Dragovich, T.; Tate, W.R.; Ramanathan, R.K.; Roe, D.; Hsu, C.H.; Kirkpatrick, D.L.; Powis, G. The antitumor thioredoxin-1 inhibitor PX-12 (1-methylpropyl 2-imidazolyl disulfide) decreases thioredoxin-1 and VEGF levels in cancer patient plasma. J. Lab. Clin. Med. 2006, 147, 83-90. [CrossRef] [PubMed]

98. Rocha, C.R.; Garcia, C.C.; Vieira, D.B.; Quinet, A.; de Andrade-Lima, L.C.; Munford, V.; Belizario, J.E.; Menck, C.F. Glutathione depletion sensitizes cisplatin- and temozolomide-resistant glioma cells in vitro and in vivo. Cell Death Dis. 2014, 5, e1505. [CrossRef] [PubMed]

99. Harris, I.S.; Treloar, A.E.; Inoue, S.; Sasaki, M.; Gorrini, C.; Lee, K.C.; Yung, K.Y.; Brenner, D.; Knobbe-Thomsen, C.B.; Cox, M.A.; et al. Glutathione and thioredoxin antioxidant pathways synergize to drive cancer initiation and progression. Cancer Cell 2015, 27, 211-222. [CrossRef]

100. Watson, J. Oxidants, antioxidants and the current incurability of metastatic cancers. Open Biol. 2013, 3, 120144. [CrossRef] [PubMed]

101. Outten, C.E.; Culotta, V.C. A novel NADH kinase is the mitochondrial source of NADPH in Saccharomyces cerevisiae. EMBO J. 2003, 22, 2015-2024. [CrossRef] [PubMed]

102. Oh, G.S.; Kim, H.J.; Choi, J.H.; Shen, A.; Choe, S.K.; Karna, A.; Lee, S.H.; Jo, H.J.; Yang, S.H.; Kwak, T.H.; et al. Pharmacological activation of $\mathrm{NQO} 1$ increases $\mathrm{NAD}(+)$ levels and attenuates cisplatin-mediated acute kidney injury in mice. Kidney Int. 2014, 85, 547-560. [CrossRef]

103. Yu, W.; Chen, Y.; Dubrulle, J.; Stossi, F.; Putluri, V.; Sreekumar, A.; Putluri, N.; Baluya, D.; Lai, S.Y.; Sandulache, V.C. Cisplatin generates oxidative stress which is accompanied by rapid shifts in central carbon metabolism. Sci. Rep. 2018, 8, 4306. [CrossRef] [PubMed]

104. Dworakowski, R.; Anilkumar, N.; Zhang, M.; Shah, A.M. Redox signalling involving NADPH oxidase-derived reactive oxygen species. Biochem. Soc. Trans. 2006, 34, 960-964. [CrossRef]

105. Infanger, D.W.; Sharma, R.V.; Davisson, R.L. NADPH oxidases of the brain: Distribution, regulation, and function. Antioxid. Redox Signal. 2006, 8, 1583-1596. [CrossRef]

106. Spencer, N.Y.; Yan, Z.; Boudreau, R.L.; Zhang, Y.; Luo, M.; Li, Q.; Tian, X.; Shah, A.M.; Davisson, R.L.; Davidson, B.; et al. Control of hepatic nuclear superoxide production by glucose 6-phosphate dehydrogenase and NADPH oxidase-4. J. Biol. Chem. 2011, 286, 8977-8987. [CrossRef]

107. Dikalov, S. Cross talk between mitochondria and NADPH oxidases. Free Radic. Biol. Med. 2011, 51, 1289-1301. [CrossRef]

108. Pan, C.; Jin, L.; Wang, X.; Li, Y.; Chun, J.; Boese, A.C.; Li, D.; Kang, H.B.; Zhang, G.; Zhou, L.; et al. Inositol-triphosphate 3-kinase B confers cisplatin resistance by regulating NOX4-dependent redox balance. J. Clin. Invest. 2019, 130. [CrossRef] [PubMed]

109. Virag, L.; Szabo, C. The therapeutic potential of poly(ADP-ribose) polymerase inhibitors. Pharmacol. Rev. 2002, 54, 375-429. [CrossRef]

110. Ying, W. NAD+ and NADH in cellular functions and cell death. Front Biosci. 2006, 11, 3129-3148. [CrossRef] [PubMed]

111. Krishnakumar, R.; Kraus, W.L. The PARP side of the nucleus: Molecular actions, physiological outcomes, and clinical targets. Mol. Cell 2010, 39, 8-24. [CrossRef] [PubMed]

112. Strom, C.E.; Johansson, F.; Uhlen, M.; Szigyarto, C.A.; Erixon, K.; Helleday, T. Poly (ADP-ribose) polymerase (PARP) is not involved in base excision repair but PARP inhibition traps a single-strand intermediate. Nucleic Acids Res. 2011, 39, $3166-3175$. [CrossRef] [PubMed]

113. Bai, P.; Canto, C.; Brunyanszki, A.; Huber, A.; Szanto, M.; Cen, Y.; Yamamoto, H.; Houten, S.M.; Kiss, B.; Oudart, H.; et al. PARP-2 regulates SIRT1 expression and whole-body energy expenditure. Cell Metab. 2011, 13, 450-460. [CrossRef] [PubMed]

114. Kolthur-Seetharam, U.; Dantzer, F.; McBurney, M.W.; de Murcia, G.; Sassone-Corsi, P. Control of AIF-mediated cell death by the functional interplay of SIRT1 and PARP-1 in response to DNA damage. Cell Cycle 2006, 5, 873-877. [CrossRef]

115. Gibson, B.A.; Kraus, W.L. New insights into the molecular and cellular functions of poly(ADP-ribose) and PARPs. Nat. Rev. Mol. Cell Biol. 2012, 13, 411-424. [CrossRef]

116. El-Khamisy, S.F.; Masutani, M.; Suzuki, H.; Caldecott, K.W. A requirement for PARP-1 for the assembly or stability of XRCC1 nuclear foci at sites of oxidative DNA damage. Nucleic Acids Res. 2003, 31, 5526-5533. [CrossRef]

117. Michels, J.; Vitale, I.; Galluzzi, L.; Adam, J.; Olaussen, K.A.; Kepp, O.; Senovilla, L.; Talhaoui, I.; Guegan, J.; Enot, D.P.; et al. Cisplatin resistance associated with PARP hyperactivation. Cancer Res. 2013, 73, 2271-2280. [CrossRef]

118. Wang, J.; Kho, D.H.; Zhou, J.Y.; Davis, R.J.; Wu, G.S. MKP-1 suppresses PARP-1 degradation to mediate cisplatin resistance. Oncogene 2017, 36, 5939-5947. [CrossRef]

119. Bai, P.; Canto, C.; Oudart, H.; Brunyanszki, A.; Cen, Y.; Thomas, C.; Yamamoto, H.; Huber, A.; Kiss, B.; Houtkooper, R.H.; et al. PARP-1 inhibition increases mitochondrial metabolism through SIRT1 activation. Cell Metab. 2011, 13, 461-468. [CrossRef]

120. Imai, S.I.; Guarente, L. It takes two to tango: $\mathrm{NAD}(+)$ and sirtuins in aging/longevity control. NPJ Aging Mech. Dis. 2016, 2, 16017. [CrossRef] 
121. Mvunta, D.H.; Miyamoto, T.; Asaka, R.; Yamada, Y.; Ando, H.; Higuchi, S.; Ida, K.; Kashima, H.; Shiozawa, T. SIRT1 Regulates the Chemoresistance and Invasiveness of Ovarian Carcinoma Cells. Transl. Oncol. 2017, 10, 621-631. [CrossRef] [PubMed]

122. Asaka, R.; Miyamoto, T.; Yamada, Y.; Ando, H.; Mvunta, D.H.; Kobara, H.; Shiozawa, T. Sirtuin 1 promotes the growth and cisplatin resistance of endometrial carcinoma cells: A novel therapeutic target. Lab. Invest. 2015, 95, 1363-1373. [CrossRef]

123. Lin, R.; Tao, R.; Gao, X.; Li, T.; Zhou, X.; Guan, K.L.; Xiong, Y.; Lei, Q.Y. Acetylation stabilizes ATP-citrate lyase to promote lipid biosynthesis and tumor growth. Mol. Cell 2013, 51, 506-518. [CrossRef]

124. Li, Z.; Xie, Q.R.; Chen, Z.; Lu, S.; Xia, W. Regulation of SIRT2 levels for human non-small cell lung cancer therapy. Lung Cancer 2013, 82, 9-15. [CrossRef] [PubMed]

125. Schlicker, C.; Gertz, M.; Papatheodorou, P.; Kachholz, B.; Becker, C.F.; Steegborn, C. Substrates and regulation mechanisms for the human mitochondrial sirtuins Sirt3 and Sirt5. J. Mol. Biol. 2008, 382, 790-801. [CrossRef] [PubMed]

126. Morigi, M.; Perico, L.; Rota, C.; Longaretti, L.; Conti, S.; Rottoli, D.; Novelli, R.; Remuzzi, G.; Benigni, A. Sirtuin 3-dependent mitochondrial dynamic improvements protect against acute kidney injury. J. Clin. Invest. 2015, 125, 715-726. [CrossRef]

127. Ahuja, N.; Schwer, B.; Carobbio, S.; Waltregny, D.; North, B.J.; Castronovo, V.; Maechler, P.; Verdin, E. Regulation of insulin secretion by SIRT4, a mitochondrial ADP-ribosyltransferase. J. Biol. Chem. 2007, 282, 33583-33592. [CrossRef]

128. Jeong, S.M.; Hwang, S.; Seong, R.H. SIRT4 regulates cancer cell survival and growth after stress. Biochem. Biophys. Res. Commun. 2016, 470, 251-256. [CrossRef]

129. Mathias, R.A.; Greco, T.M.; Oberstein, A.; Budayeva, H.G.; Chakrabarti, R.; Rowland, E.A.; Kang, Y.; Shenk, T.; Cristea, I.M Sirtuin 4 is a lipoamidase regulating pyruvate dehydrogenase complex activity. Cell 2014, 159, 1615-1625. [CrossRef] [PubMed]

130. Lu, W.; Zuo, Y.; Feng, Y.; Zhang, M. SIRT5 facilitates cancer cell growth and drug resistance in non-small cell lung cancer. Tumour. Biol. 2014, 35, 10699-10705. [CrossRef]

131. Mao, Z.; Hine, C.; Tian, X.; Van Meter, M.; Au, M.; Vaidya, A.; Seluanov, A.; Gorbunova, V. SIRT6 promotes DNA repair under stress by activating PARP1. Science 2011, 332, 1443-1446. [CrossRef]

132. Dominy, J.E., Jr.; Lee, Y.; Jedrychowski, M.P.; Chim, H.; Jurczak, M.J.; Camporez, J.P.; Ruan, H.B.; Feldman, J.; Pierce, K.; Mostoslavsky, R.; et al. The deacetylase Sirt6 activates the acetyltransferase GCN5 and suppresses hepatic gluconeogenesis. Mol. Cell 2012, 48, 900-913. [CrossRef] [PubMed]

133. Zhong, L.; D’Urso, A.; Toiber, D.; Sebastian, C.; Henry, R.E.; Vadysirisack, D.D.; Guimaraes, A.; Marinelli, B.; Wikstrom, J.D.; Nir, T.; et al. The histone deacetylase Sirt6 regulates glucose homeostasis via Hif1alpha. Cell 2010, 140, 280-293. [CrossRef]

134. Lim, J.H.; Lee, Y.M.; Chun, Y.S.; Chen, J.; Kim, J.E.; Park, J.W. Sirtuin 1 modulates cellular responses to hypoxia by deacetylating hypoxia-inducible factor 1alpha. Mol. Cell 2010, 38, 864-878. [CrossRef]

135. Miyasato, Y.; Yoshizawa, T.; Sato, Y.; Nakagawa, T.; Miyasato, Y.; Kakizoe, Y.; Kuwabara, T.; Adachi, M.; Ianni, A.; Braun, T.; et al. Sirtuin 7 Deficiency Ameliorates Cisplatin-induced Acute Kidney Injury Through Regulation of the Inflammatory Response. Sci. Rep. 2018, 8, 5927. [CrossRef] [PubMed]

136. Kouidhi, S.; Ben Ayed, F; Benammar Elgaaied, A. Targeting Tumor Metabolism: A New Challenge to Improve Immunotherapy. Front. Immunol. 2018, 9, 353. [CrossRef] [PubMed]

137. Fox, C.J.; Hammerman, P.S.; Thompson, C.B. Fuel feeds function: Energy metabolism and the T-cell response. Nat. Rev. Immunol. 2005, 5, 844-852. [CrossRef]

138. Jones, R.G.; Thompson, C.B. Revving the engine: Signal transduction fuels T cell activation. Immunity 2007, 27, 173-178. [CrossRef]

139. Triplett, T.A.; Garrison, K.C.; Marshall, N.; Donkor, M.; Blazeck, J.; Lamb, C.; Qerqez, A.; Dekker, J.D.; Tanno, Y.; Lu, W.C.; et al. Reversal of indoleamine 2,3-dioxygenase-mediated cancer immune suppression by systemic kynurenine depletion with a therapeutic enzyme. Nat. Biotechnol. 2018, 36, 758-764. [CrossRef]

140. Ben-Shoshan, J.; Maysel-Auslender, S.; Mor, A.; Keren, G.; George, J. Hypoxia controls CD4+CD25+ regulatory T-cell homeostasis via hypoxia-inducible factor-1alpha. Eur. J. Immunol. 2008, 38, 2412-2418. [CrossRef]

141. Noman, M.Z.; Desantis, G.; Janji, B.; Hasmim, M.; Karray, S.; Dessen, P.; Bronte, V.; Chouaib, S. PD-L1 is a novel direct target of HIF-1alpha, and its blockade under hypoxia enhanced MDSC-mediated T cell activation. J. Exp. Med. 2014, 211, 781-790. [CrossRef]

142. Mu, C.Y.; Huang, J.A.; Chen, Y.; Chen, C.; Zhang, X.G. High expression of PD-L1 in lung cancer may contribute to poor prognosis and tumor cells immune escape through suppressing tumor infiltrating dendritic cells maturation. Med. Oncol. 2011, 28, 682-688. [CrossRef] [PubMed]

143. Fournel, L.; Wu, Z.; Stadler, N.; Damotte, D.; Lococo, F.; Boulle, G.; Segal-Bendirdjian, E.; Bobbio, A.; Icard, P.; Tredaniel, J.; et al. Cisplatin increases PD-L1 expression and optimizes immune check-point blockade in non-small cell lung cancer. Cancer Lett. 2019, 464, 5-14. [CrossRef] [PubMed]

144. Zerdes, I.; Wallerius, M.; Sifakis, E.G.; Wallmann, T.; Betts, S.; Bartish, M.; Tsesmetzis, N.; Tobin, N.P.; Coucoravas, C.; Bergh, J.; et al. STAT3 Activity Promotes Programmed-Death Ligand 1 Expression and Suppresses Immune Responses in Breast Cancer. Cancers 2019, 11, 1479. [CrossRef] [PubMed]

145. Zhang, Q.; Wang, H.Y.; Woetmann, A.; Raghunath, P.N.; Odum, N.; Wasik, M.A. STAT3 induces transcription of the DNA methyltransferase 1 gene (DNMT1) in malignant T lymphocytes. Blood 2006, 108, 1058-1064. [CrossRef]

146. Yan, F.; Pang, J.; Peng, Y.; Molina, J.R.; Yang, P.; Liu, S. Elevated Cellular PD1/PD-L1 Expression Confers Acquired Resistance to Cisplatin in Small Cell Lung Cancer Cells. PLoS ONE 2016, 11, e0162925. [CrossRef] [PubMed] 
147. Guillemin, G.J.; Brew, B.J. Implications of the kynurenine pathway and quinolinic acid in Alzheimer's disease. Redox Rep. 2002, 7, 199-206. [CrossRef]

148. Henderson, L.M.; Gross, C.J. Metabolism of niacin and niacinamide in perfused rat intestine. J. Nutr. 1979, 109, 654-662. [CrossRef]

149. Institute of Medicine (US) Standing Committee on the Scientific Evaluation of Dietary Reference Intakes and its Panel on Folate; Other B Vitamins; Choline. Dietary Reference Intakes for Thiamin, Riboflovin, Niacin, Vitamin B6, Folate, Vitamin B12, Pantothenic Acid, Biotin, and Choline; National Academies Press (US): Washington, DC, USA, 1998.

150. Hara, N.; Yamada, K.; Shibata, T.; Osago, H.; Hashimoto, T.; Tsuchiya, M. Elevation of cellular NAD levels by nicotinic acid and involvement of nicotinic acid phosphoribosyltransferase in human cells. J. Biol. Chem. 2007, 282, 24574-24582. [CrossRef]

151. Peters, J.C. Tryptophan nutrition and metabolism: An overview. Adv. Exp. Med. Biol. 1991, 294, 345-358.

152. Davis, I.; Liu, A. What is the tryptophan kynurenine pathway and why is it important to neurotherapeutics? Expert Rev. Neurother. 2015, 15, 719-721. [CrossRef]

153. Wang, X.; Dong, H.; Li, Q.; Li, Y.; Hong, A. Thioredoxin induces Tregs to generate an immunotolerant tumor microenvironment in metastatic melanoma. Oncoimmunology 2015, 4, e1027471. [CrossRef]

154. de Araujo, E.F.; Feriotti, C.; Galdino, N.A.L.; Preite, N.W.; Calich, V.L.G.; Loures, F.V. The IDO-AhR Axis Controls Th17/Treg Immunity in a Pulmonary Model of Fungal Infection. Front. Immunol. 2017, 8, 880. [CrossRef]

155. Platten, M.; von Knebel Doeberitz, N.; Oezen, I.; Wick, W.; Ochs, K. Cancer Immunotherapy by Targeting IDO1/TDO and Their Downstream Effectors. Front. Immunol. 2014, 5, 673. [CrossRef]

156. Campia, I.; Buondonno, I.; Castella, B.; Rolando, B.; Kopecka, J.; Gazzano, E.; Ghigo, D.; Riganti, C. An Autocrine Cytokine/JAK/STAT-Signaling Induces Kynurenine Synthesis in Multidrug Resistant Human Cancer Cells. PLoS ONE 2015, 10, e0126159. [CrossRef] [PubMed]

157. Okamoto, A.; Nikaido, T.; Ochiai, K.; Takakura, S.; Saito, M.; Aoki, Y.; Ishii, N.; Yanaihara, N.; Yamada, K.; Takikawa, O.; et al. Indoleamine 2,3-dioxygenase serves as a marker of poor prognosis in gene expression profiles of serous ovarian cancer cells. Clin. Cancer Res. 2005, 11, 6030-6039. [CrossRef] [PubMed]

158. Komiya, T.; Huang, C.H. Updates in the Clinical Development of Epacadostat and Other Indoleamine 2,3-Dioxygenase 1 Inhibitors (IDO1) for Human Cancers. Front. Oncol. 2018, 8, 423. [CrossRef] [PubMed]

159. Mullard, A. IDO takes a blow. Nat. Rev. Drug Discov. 2018, 17, 307. [CrossRef] [PubMed]

160. Simons, A.L.; Ahmad, I.M.; Mattson, D.M.; Dornfeld, K.J.; Spitz, D.R. 2-Deoxy-D-glucose combined with cisplatin enhances cytotoxicity via metabolic oxidative stress in human head and neck cancer cells. Cancer Res. 2007, 67, 3364-3370. [CrossRef] [PubMed]

161. Wangpaichitr, M.; Savaraj, N.; Maher, J.; Kurtoglu, M.; Lampidis, T.J. Intrinsically lower AKT, mammalian target of rapamycin, and hypoxia-inducible factor activity correlates with increased sensitivity to 2-deoxy-D-glucose under hypoxia in lung cancer cell lines. Mol. Cancer Ther. 2008, 7, 1506-1513. [CrossRef]

162. Manerba, M.; Di Ianni, L.; Fiume, L.; Roberti, M.; Recanatini, M.; Di Stefano, G. Lactate dehydrogenase inhibitors sensitize lymphoma cells to cisplatin without enhancing the drug effects on immortalized normal lymphocytes. Eur. J. Pharm. Sci. 2015, 74, 95-102. [CrossRef]

163. Tataranni, T.; Piccoli, C. Dichloroacetate (DCA) and Cancer: An Overview towards Clinical Applications. Oxidative Med. Cell. Longev. 2019, 2019, 8201079. [CrossRef] [PubMed]

164. Pillozzi, S.; D’Amico, M.; Bartoli, G.; Gasparoli, L.; Petroni, G.; Crociani, O.; Marzo, T.; Guerriero, A.; Messori, L.; Severi, M.; et al. The combined activation of KCa3.1 and inhibition of Kv11.1/hERG1 currents contribute to overcome Cisplatin resistance in colorectal cancer cells. Br. J. Cancer 2018, 118, 200-212. [CrossRef] [PubMed]

165. Chen, L.; Cui, H.; Fang, J.; Deng, H.; Kuang, P.; Guo, H.; Wang, X.; Zhao, L. Glutamine deprivation plus BPTES alters etoposideand cisplatin-induced apoptosis in triple negative breast cancer cells. Oncotarget 2016, 7, 54691-54701. [CrossRef]

166. Gross, M.I.; Demo, S.D.; Dennison, J.B.; Chen, L.; Chernov-Rogan, T.; Goyal, B.; Janes, J.R.; Laidig, G.J.; Lewis, E.R.; Li, J.; et al. Antitumor activity of the glutaminase inhibitor CB-839 in triple-negative breast cancer. Mol. Cancer Ther. 2014, 13, 890-901. [CrossRef]

167. Jin, H.; Wang, S.; Zaal, E.A.; Wang, C.; Wu, H.; Bosma, A.; Jochems, F.; Isima, N.; Jin, G.; Lieftink, C.; et al. A powerful drug combination strategy targeting glutamine addiction for the treatment of human liver cancer. eLife 2020, 9. [CrossRef]

168. Mazumder, M.E.; Beale, P.; Chan, C.; Yu, J.Q.; Huq, F. Epigallocatechin gallate acts synergistically in combination with cisplatin and designed trans-palladiums in ovarian cancer cells. AntiCancer Res. 2012, 32, 4851-4860.

169. Hu, F.; Wei, F.; Wang, Y.; Wu, B.; Fang, Y.; Xiong, B. EGCG synergizes the therapeutic effect of cisplatin and oxaliplatin through autophagic pathway in human colorectal cancer cells. J. Pharmacol. Sci. 2015, 128, 27-34. [CrossRef]

170. Vazquez-Martin, A.; Colomer, R.; Brunet, J.; Lupu, R.; Menendez, J.A. Overexpression of fatty acid synthase gene activates HER1/HER2 tyrosine kinase receptors in human breast epithelial cells. Cell Prolif. 2008, 41, 59-85. [CrossRef]

171. Puig, T.; Turrado, C.; Benhamu, B.; Aguilar, H.; Relat, J.; Ortega-Gutierrez, S.; Casals, G.; Marrero, P.F.; Urruticoechea, A.; Haro, D.; et al. Novel Inhibitors of Fatty Acid Synthase with Anticancer Activity. Clin. Cancer Res. 2009, 15, 7608-7615. [CrossRef] [PubMed]

172. Papaevangelou, E.; Almeida, G.S.; Box, C.; deSouza, N.M.; Chung, Y.L. The effect of FASN inhibition on the growth and metabolism of a cisplatin-resistant ovarian carcinoma model. Int. J. Cancer 2018, 143, 992-1002. [CrossRef] 
173. Imai, H.; Kaira, K.; Oriuchi, N.; Shimizu, K.; Tominaga, H.; Yanagitani, N.; Sunaga, N.; Ishizuka, T.; Nagamori, S.; Promchan, K.; et al. Inhibition of L-type amino acid transporter 1 has antitumor activity in non-small cell lung cancer. AntiCancer Res. 2010, 30, $4819-4828$

174. Huttunen, K.M.; Gynther, M.; Huttunen, J.; Puris, E.; Spicer, J.A.; Denny, W.A. A Selective and Slowly Reversible Inhibitor of 1-Type Amino Acid Transporter 1 (LAT1) Potentiates Antiproliferative Drug Efficacy in Cancer Cells. J. Med. Chem. 2016, 59, 5740-5751. [CrossRef] [PubMed]

175. Yi, J.; Liu, X.; Li, F. Esophageal Angiolipoma: A Tongue-Like Mucosal Mass. Clin. Gastroenterol. Hepatol. 2021, 19, e49-e50. [CrossRef] [PubMed]

176. Nguyen, D.J.M.; Theodoropoulos, G.; Li, Y.Y.; Wu, C.; Sha, W.; Feun, L.G.; Lampidis, T.J.; Savaraj, N.; Wangpaichitr, M. Targeting the Kynurenine Pathway for the Treatment of Cisplatin-Resistant Lung Cancer. Mol. Cancer Res. 2020, 18, 105-117. [CrossRef]

177. Jia, Y.; Zhang, W.; Liu, H.; Peng, L.; Yang, Z.; Lou, J. Inhibition of glutathione synthesis reverses Kruppel-like factor 4-mediated cisplatin resistance. Cancer Chemother. Pharmacol. 2012, 69, 377-385. [CrossRef]

178. Haas, B.; Schutte, L.; Wos-Maganga, M.; Weickhardt, S.; Timmer, M.; Eckstein, N. Thioredoxin Confers Intrinsic Resistance to Cytostatic Drugs in Human Glioma Cells. Int. J. Mol. Sci. 2018, 19, 2874. [CrossRef] [PubMed]

179. Kirshner, J.R.; He, S.; Balasubramanyam, V.; Kepros, J.; Yang, C.Y.; Zhang, M.; Du, Z.; Barsoum, J.; Bertin, J. Elesclomol induces cancer cell apoptosis through oxidative stress. Mol. Cancer Ther. 2008, 7, 2319-2327. [CrossRef] [PubMed]

180. Ogihara, K.; Kikuchi, E.; Okazaki, S.; Hagiwara, M.; Takeda, T.; Matsumoto, K.; Kosaka, T.; Mikami, S.; Saya, H.; Oya, M. Sulfasalazine could modulate the CD44v9-xCT system and enhance cisplatin-induced cytotoxic effects in metastatic bladder cancer. Cancer Sci. 2019, 110, 1431-1441. [CrossRef]

181. Stanford, E.A.; Ramirez-Cardenas, A.; Wang, Z.; Novikov, O.; Alamoud, K.; Koutrakis, P.; Mizgerd, J.P.; Genco, C.A.; Kukuruzinska, M.; Monti, S.; et al. Role for the Aryl Hydrocarbon Receptor and Diverse Ligands in Oral Squamous Cell Carcinoma Migration and Tumorigenesis. Mol. Cancer Res. 2016, 14, 696-706. [CrossRef] 